NATIONAL LABORATORY

\title{
Initial Assessment of Environmental Effects on SiC/SiC composites in Helium-cooled Nuclear Systems
}

September 2013

Prepared by

Cristian I Contescu

Sr. Research Staff Scientist

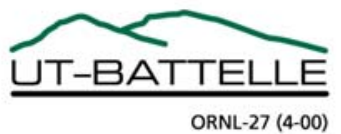




\title{
DOCUMENT AVAILABILITY
}

Reports produced after January 1, 1996, are generally available free via the U.S. Department of Energy (DOE) Information Bridge.

Web site http://www.osti.gov/bridge

Reports produced before January 1, 1996, may be purchased by members of the public from the following source.

\author{
National Technical Information Service \\ 5285 Port Royal Road \\ Springfield, VA 22161 \\ Telephone 703-605-6000 (1-800-553-6847) \\ TDD 703-487-4639 \\ Fax 703-605-6900 \\ E-mail info@ntis.gov \\ Web site http://www.ntis.gov/support/ordernowabout.htm
}

Reports are available to DOE employees, DOE contractors, Energy Technology Data Exchange (ETDE) representatives, and International Nuclear Information System (INIS) representatives from the following source.

Office of Scientific and Technical Information

P.O. Box 62

Oak Ridge, TN 37831

Telephone 865-576-8401

Fax 865-576-5728

E-mail reports@osti.gov

Web site http://www.osti.gov/contact.html

This report was prepared as an account of work sponsored by an agency of the United States Government. Neither the United States Government nor any agency thereof, nor any of their employees, makes any warranty, express or implied, or assumes any legal liability or responsibility for the accuracy, completeness, or usefulness of any information, apparatus, product, or process disclosed, or represents that its use would not infringe privately owned rights. Reference herein to any specific commercial product, process, or service by trade name, trademark, manufacturer, or otherwise, does not necessarily constitute or imply its endorsement, recommendation, or favoring by the United States Government or any agency thereof. The views and opinions of authors expressed herein do not necessarily state or reflect those of the United States Government or any agency thereof. 
ORNL/TM-2013/319

\title{
INITIAL ASSESSMENT OF ENVIRONMENTAL EFFECTS ON SiC/SiC COMPOSITES IN HELIUM-COOLED NUCLEAR REACTOR SYSTEMS
}

\author{
Cristian I Contescu
}

Date Published:

September 2013

Prepared by

OAK RIDGE NATIONAL LABORATORY

Oak Ridge, Tennessee 37831-6283

managed by

UT-BATTELLE, LLC

for the

U.S. DEPARTMENT OF ENERGY

under contract DE-AC05-00OR22725 



\section{CONTENTS}

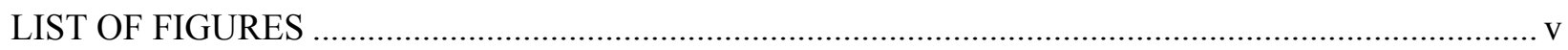

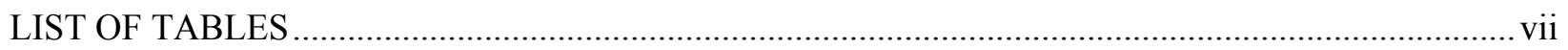

LIST OF ABBREVIATIONS......................................................... vii

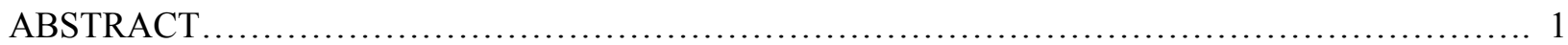

1. SIC/SIC COMPOSITES AS NUCLEAR STRUCTURAL MATERIALS .................................... 3

1.1 TYPES, PROPERTIES, APPLICATIONS ......................................................................... 3

1.2 ENVIRONMENTAL CONDITIONS IN HELIUM-COOLED HIGH TEMPERATURE

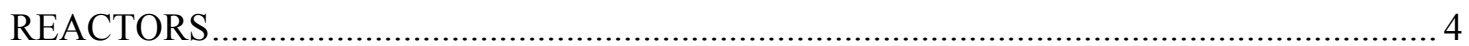

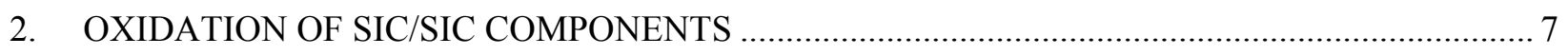

2.1 OXIDATION OF MASSIVE SiC ............................................................................ 7

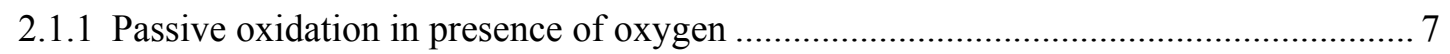

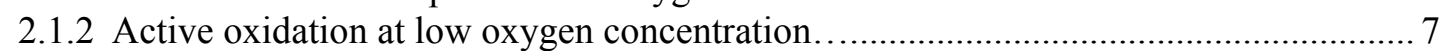

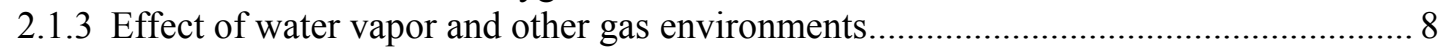

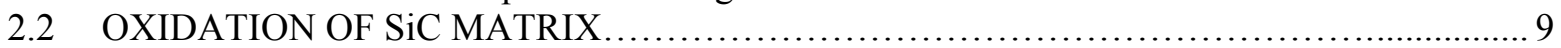

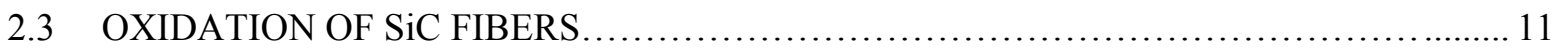

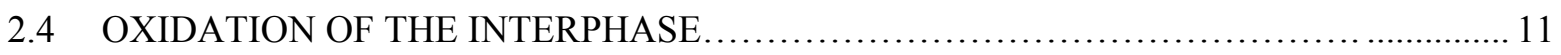

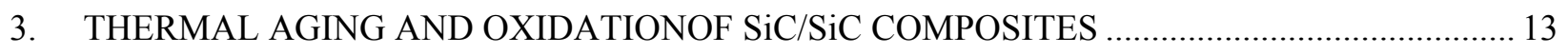

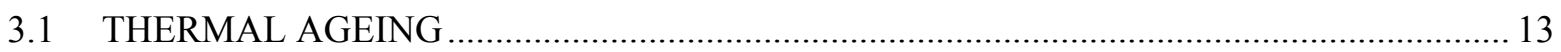

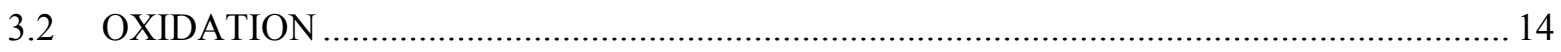

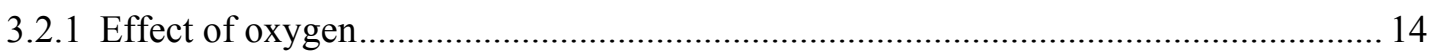

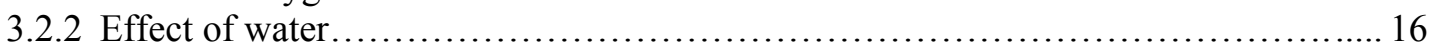

3.2.3. Environmental effects on fatigue behavior......................................... 17

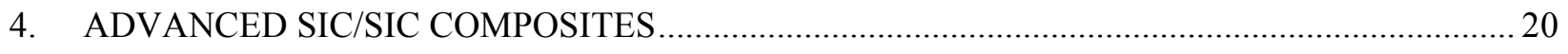

4.1 ENGINEERED COMPOSITES WITH IMPROVED OXIDATION STABILITY ................ 20

4.2 ENGINEERED COMPOSITES FOR USE IN NUCLEAR APPLICATIONS ........................ 22

5. CHEMICAL COMPATIBILITY OF SIC/SIC COMPOSITES IN THE ENVIRONMENT OF

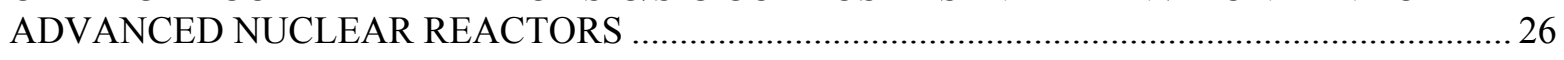

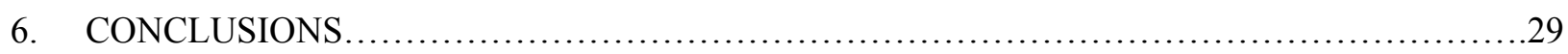

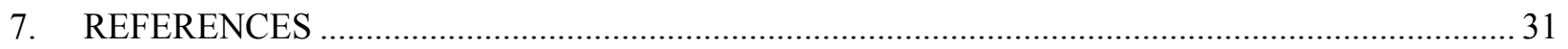





\section{LIST OF FIGURES}

1 Optical micrographs showing development of crystobalite at the surface of SiC sample treated at $1500^{\circ} \mathrm{C}$ in a flow of pure oxygen.

2 Arrhenius plots showing theoretical and experimetnal transitions between passive and active oxidation for $\alpha-\mathrm{SiC}$ (transition a) and $\beta-\mathrm{SiC}$ (transition $b$ ).

$3 \quad$ SEM images of $\alpha$-SiC oxidized under $P_{\mathrm{O} 2}=0.2 \mathrm{~Pa}$ at (from top to bottom) $1553 \mathrm{~K}$; $1600 \mathrm{~K}$, and $1900 \mathrm{~K}$ (left); and under $P_{\mathrm{O} 2}=100 \mathrm{~Pa}$ at (from top to bottom) $1673 \mathrm{~K}$; $1762 \mathrm{~K}$, and $2059 \mathrm{~K}$ (right)

4

SEM images of $\beta$-SiC oxidized under $P_{\mathrm{O} 2}=0.2 \mathrm{~Pa}$ at (from top to bottom) $1595 \mathrm{~K}$; $1653 \mathrm{~K}$, and $2120 \mathrm{~K}$ (left); and under $P_{\mathrm{O} 2}=100 \mathrm{~Pa}$ at (from top to bottom) $1739 \mathrm{~K}$; $1900 \mathrm{~K}$, and $2119 \mathrm{~K}$ (right).

Oxygen partial pressure for active-to-passive oxidation transition of $\mathrm{SiC}$ as a function of temperatures, showing continuous improvement of oxidation resistance over three generations of $\mathrm{SiC}$ fibers.

SEM image of pyrocarbon-infiltrated carbon fiber tow showing that pyrocarbon has higher oxidation resistance.

Microstructure of $\mathrm{SiC} / \mathrm{SiC}$ composites formed with $\mathrm{SiC}$ fibers of three generations, after ageing in vacuum at high temperatures.....

Composite weight changes caused by exposure in vacuum and in air at 700,1200, and $1400{ }^{\circ} \mathrm{C}$

(Left): Typical silica scale morphology observed for CVD $\beta$-SiC after $500 \mathrm{~h}$ exposure to 10 bar air $+\mathrm{H}_{2} \mathrm{O}$ at $1200{ }^{\circ} \mathrm{C}$; (Right): Silica scale on sintered $\beta$-SiC after $100 \mathrm{~h}$ exposure to 10 bar of (a) air and (b) air $+\mathrm{H}_{2} \mathrm{O}$ at $1200{ }^{\circ} \mathrm{C}$. The arrows show the dense silica layer. Only this layer was formed when no $\mathrm{H}_{2} \mathrm{O}$ was present.

Evolution of cyclic fatigue tests of $2 \mathrm{D} \mathrm{SiC} / \mathrm{SiC}$ composites (Nicalon fibers) as received (left) and after vacuum treatment at $800{ }^{\circ} \mathrm{C}$ for $50 \mathrm{~h}$, showing different behavior during 500,000 cycles of mechanical hysteresis, indicative of evolution of interfacial shear stress between fibers and matrix.

11 Fracture surface of specimens tested in tension-compression mode at $1200{ }^{\circ} \mathrm{C}$ conducted in (a) air at $160 \mathrm{MPa}$ after 23,277 cycles; (b) in air at $80 \mathrm{MPa}$ after 200,000 cycles, and (c) in steam at $160 \mathrm{MPa}$ after 2214 cycles.

$\mathrm{SiC} / \mathrm{SiC}$ composite with four sequences of $\mathrm{PyC} / \mathrm{SiC}$ interphase layers

13 TEM micrographs showing the deflection of matrix cracks in multilayered interphase composites of the first (left) and second (right) generation.

14 Mass loss rates of $\beta$-SiC-SiC/PyC/SiC composites oxidized in helium containing low concentrations of oxygen $(0.2$ and $2 \mathrm{~Pa})$.

15 Mass loss rate versus temperature for monolithic $\beta$-SiC and $\beta-\mathrm{SiC}-\mathrm{SiC} / \mathrm{PyC} / \mathrm{SiC}$ composite in helium (with $2 \mathrm{~Pa} \mathrm{O}_{2}$ ), air and nitrogen (with $0.5 \mathrm{~Pa} \mathrm{O}_{2}$ ).

16 Top: Weight change during exposure to helium containing $150 \mathrm{~Pa} \mathrm{O}_{2}$ of conventional $\mathrm{PyC}-\mathrm{SiC} / \mathrm{SiC}$ composite and of multilayer ML-SiC/SiC composite. The behavior of monolithic $\beta-\mathrm{SiC}$ and graphite is shown for comparison. Bottom: Schematic diagram of the oxidation mechanism of $\mathrm{PyC}-\mathrm{SiC} / \mathrm{SiC}$ composite. 


\section{LIST OF TABLES}

Table

Page

1 Impurity content in helium-cooled high temperature reactors 5

\section{LIST OF ABBREVIATIONS}

$\begin{array}{ll}\text { 1D } & \text { uni-dimensional } \\ \text { 2D } & \text { two-dimensional } \\ \text { 3D } & \text { three-dimensional } \\ \text { C/C } & \text { carbon fiber / carbon matrix (composites) } \\ \text { CVD } & \text { chemical vapor deposition } \\ \text { CVI } & \text { chemical vapor impregnation } \\ \text { EBC } & \text { Environmental Barrier Coating } \\ \text { FHR } & \text { Fluoride-cooled High-temperature Reactor } \\ \text { GFR } & \text { Gas Fast Reactor } \\ \text { HCSB } & \text { Helium Cooled Solid Breeder } \\ \text { HTGR } & \text { High Temperature Gas-cooled Reactor } \\ \text { HTR } & \text { High Temperature Reactor } \\ \text { HTTR } & \text { High Temperature Test Reactor } \\ \text { LWR } & \text { Light Water Reactor } \\ \text { NGNP } & \text { Next Generation Nuclear Plant } \\ \text { NITE } & \text { nano-infiltration and transient eutectic (process) } \\ \text { ML } & \text { multilayer } \\ \text { PIP } & \text { Precursor Infiltration and Pyrolysis (method) } \\ \text { ppm } & \text { parts per million } \\ \text { PyC } & \text { pyrolytic carbon (aka pyrocarbon) } \\ \text { SFR } & \text { Sodium Fast Reactors } \\ \text { SiC } & \text { silicon carbide } \\ \text { VHTR } & \text { Very High Temperature Reactors }\end{array}$




\begin{abstract}
Ceramic matrix composites, in particular $\mathrm{SiC} / \mathrm{SiC}$ composites, are currently being evaluated for use at high temperatures and high radiation fields in advanced concept reactors, including high-temperature gas cooled reactors (HTGR), very high temperature reactors (VHTR), gas fast reactors (GFR), sodium fast reactors (SFR) and fluoride-cooled high temperature reactors (FHR). SiC/SiC composites have many desirable properties for high temperature nuclear applications, including excellent thermal and mechanical properties and radiation resistance. However, their behavior in contact with the chemical environment in normal operation conditions and in off-normal accident conditions scenarios still needs to be evaluated. This report summarizes the information available in the literature on the chemical reactivity of SiC/SiC composites and of their components in contact with the helium coolant used in HTGR, VHTR and GFR designs. Under normal operating conditions, ultra-high purity helium will have chemically controlled impurities (water, oxygen, carbon dioxide, carbon monoxide, methane, hydrogen) that will create a slightly oxidizing gas environment. Little is known from direct experiments on the reactivity of third generation (nuclear grade) $\mathrm{SiC} / \mathrm{SiC}$ composites in contact with low concentrations of water or oxygen in inert gas, at high temperature. However, there is ample information regarding the oxidation behavior of $\mathrm{SiC} / \mathrm{SiC}$ composites in dry and moist air at high temperatures. This information is reviewed first in the next chapters. The emphasis is placed on the improvement in material oxidation, thermal, and mechanical properties during three stages of development of SiC fibers and at least two stages of development of the fiber/matrix interphase. The chemical stability of $\mathrm{SiC} / \mathrm{SiC}$ composites in contact with oxygen or steam at temperatures that may develop in off-normal reactor conditions supports the conclusion that most advanced composites (also known as nuclear grade $\mathrm{SiC} / \mathrm{SiC}$ composites) have the chemical resistance that would allow them maintain mechanical properties at temperatures up to $1200-1300{ }^{\circ} \mathrm{C}$ in the extreme conditions of an air or water ingress accident scenario. Further research is needed to assess the long-term stability of advanced $\mathrm{SiC} / \mathrm{SiC}$ composites in inert gas (helium) in presence of very low concentrations (traces) of water and oxygen at the temperatures of normal operation of helium-cooled reactors.
\end{abstract}




\section{SiC/SiC COMPOSITES AS NUCLEAR STRUCTURAL MATERIALS}

Ceramic materials are strong candidates for internal core structural components in the next generation of nuclear energy systems. Several reactor concepts are currently being analyzed; instead of pressurized water, they use for coolant either molten salts, or gaseous helium, or liquid sodium. The candidate composites are continuous fiber-reinforced materials, made of either carbon or silicon carbide fibers infiltrated with a similar matrix. While carbon-fiber composites are now a mature technology and a readily-available commercial product, the technological development of $\mathrm{SiC} / \mathrm{SiC}$ composites for commercial scale applications still continues. However, the third generation of $\mathrm{SiC} / \mathrm{SiC}$ composites, qualified as nuclear grade, has the important advantage of being far more stable to irradiation degradation. Their high resistance to intense irradiation condition is an inherent property of the isotropic SiC crystal, which undergoes only modest property changes (swelling, hardness, elastic modulus, strength) in the range of temperatures of interest for high-temperature reactors. ${ }^{1}$ In contrast, carbon-fiber composites undergo densification parallel to the fiber axis and swelling on the perpendicular direction, which is caused by the growth of new basal planes from carbon atoms displaced by neutrons in interstitial positions. This difference makes nuclear grade $\mathrm{SiC} / \mathrm{SiC}$ composites the preferred material over $\mathrm{C} / \mathrm{C}$ composites for components designed to withstand long-time exposure to intense radiation and elevated temperatures.

\subsection{TYPES, PROPERTIES, APPLICATIONS}

The attractive mechanical properties of $\mathrm{SiC} / \mathrm{SiC}$ composites (tensile strength, elastic modulus, creep resistance) originate from the reinforcing fibers. In addition, the temperature limits depend on the stability of component fibers in an inert atmosphere or in vacuum under high temperature conditions. Bonding of fibers to the matrix is ensured by a thin layer of compliant material, generally known as the interphase, which enhances the non-brittle mechanical behavior. Pyrocarbon is commonly used as the interphase.

The enhanced radiation resistance of $\mathrm{SiC} / \mathrm{SiC}$ composites is the unique property of newly developed nuclear-grade $\mathrm{SiC}$ fibers, also known as the third generation fibers. Early grades of $\mathrm{SiC}$ fibers contained either too much oxygen (first generation) or too much carbon (second generation). Thus, the Nicalon fibers of the first generation have relatively low price, good mechanical properties, and excellent weavability, but their composition should be described as $\mathrm{Si}-\mathrm{O}_{\mathrm{x}}-\mathrm{C}_{\mathrm{y}}$ rather than $\mathrm{SiC}$. Second generation Hi-Nicalon has less than $1 \%$ oxygen. The third generation fibers are nearly stoichiometric, having only a low excess of carbon in the bulk and no residual oxygen, although the surface might be covered with a thin carbon layer. Some fibers contain various amounts of additives, such as aluminum (Tyranno SA) or boron (Sylramic); Hi-Nicalon S (from Nippon Carbon) contains larger amounts of impurities. These third generation fibers have a coarse microstructure and high density, are stable up to $1800-2000{ }^{\circ} \mathrm{C}$ and maintain good mechanical properties up to $1400-1500{ }^{\circ} \mathrm{C}$, although $\mathrm{SiC}$ grains may grow larger at 2100 
${ }^{\circ} \mathrm{C}$. Tyranno-SA3 and Sylramic have even higher upper temperature limit (retain strength up to $1800{ }^{\circ} \mathrm{C}$ ), but also higher thermal creep rate at low temperatures.

The properties of $\mathrm{SiC}$ matrix depend on the fabrication route. Most common routes, compatible with the nuclear environment, are chemical vapor impregnation (CVI) and nano-infiltration and transient eutectic-phase process (NITE). Both these methods produce highly crystalline, stoichiometric matrices and can be fabricated in a variety of shapes. The CVI process, which in fact is a variety of chemical vapor deposition (CVD) of pyrolytic SiC, allows deposition of high purity, highly crystalline $\beta$-SiC phase, with excellent thermal stability and radiation resistance, but with limited matrix densification. ${ }^{2}$

The decomposition of SiC occurs at high temperatures $\left(>2500^{\circ} \mathrm{C}\right)$ :

$$
\mathrm{SiC}_{(\mathrm{s})} \rightarrow \mathrm{C}_{(\mathrm{s})}+\mathrm{Si}(\mathrm{C})_{(1)}
$$

The gas phase in equilibrium with $\mathrm{SiC}$ at temperatures below the melting point contains $\mathrm{Si}_{(\mathrm{g})}$ and $\mathrm{SiC}_{2(\mathrm{~g})}$. Thus, exposure to high temperatures under an inert environment induces thermal degradation. However, kinetic factors limit this process, so that thermal decomposition of $\mathrm{SiC}$ occurs only at temperatures above $1600{ }^{\circ} \mathrm{C}$, before melting.

Nuclear grade $\mathrm{SiC} / \mathrm{SiC}$ composites are considered candidates for components of light-water reactor (LWR) fuel cladding and channel boxes; for fuel and in-vessel components for advanced fission reactors such as high-temperature gas-cooled reactors (HTGR); for fluoride salt-cooled high temperature reactors (FHR); for gas-cooled fast reactors (GFR), and also for fusion energy and other extreme irradiation conditions. In the U.S. the reference $\mathrm{SiC} / \mathrm{SiC}$ material for the NGNP program is the composite made with Hi-Nicalon S fiber and CVI SiC matrix, with an interphase made of pyrolytic carbon and SiC. ${ }^{2}$ Several U.S. companies are known to manufacture $\mathrm{SiC} / \mathrm{SiC}$ composites by CVI. The list includes GE Energy, BF Goodrich, ad Hypertherm High-Temperature Composites (now Rolls-Royce), as well as other small businesses capable of manufacturing nuclear grade $\mathrm{SiC} / \mathrm{SiC} \mathrm{CVI}$ composites.

\subsection{ENVIRONMENT CONDITIONS IN HELIUM-COOLED HIGH TEMPERATURE REACTORS}

The coolant helium gas in high temperature reactors (HTRs) is expected to contain low level gas impurities. Of concern during normal operating conditions are oxidant species such as $\mathrm{H}_{2} \mathrm{O}, \mathrm{O}_{2}$, and $\mathrm{CO}_{2}$ that may cause slow gasification over the lifetime of components. Other impurities $\left(\mathrm{H}_{2}, \mathrm{CO}\right)$ have reducing character, and some others are neutral $\left(\mathrm{N}_{2}, \mathrm{CH}_{4}\right)$. Methane results from reaction of carbon with $\mathrm{H}_{2}$, but this gasification reaction is not probable at temperatures above $600{ }^{\circ} \mathrm{C}$. If however, methane is formed, it is a product of radiolytic processes. Other radiolytic processes may lead to formation of tritium and of some reactive ionized species.

Table 1 shows coolant gas impurities in historic high- and very high temperature gas-cooled reactors (HTGR and VHTR) and in modern reactors operated in Japan and China. Depending on design the coolant temperature (output) varies between $750{ }^{\circ} \mathrm{C}$ (Dragon, Peach Bottom) and $900-950{ }^{\circ} \mathrm{C}$ (HTTR, several NGNP design concepts). The nominal operating temperature in gas-cooled fast reactors (GFR) is even higher (about $1000{ }^{\circ} \mathrm{C}$ ). ${ }^{3}$ The main technological challenge is development of materials able to resist the damage caused by fast neutron fluences at high temperatures.

$\mathrm{SiC}$ is an excellent candidate for these extreme requirements. $\mathrm{SiC} / \mathrm{SiC}$ composites are recommended for components subjected to high fluence conditions or where anisotropic changes in dimension and 
elastic properties cannot be tolerated. Such components may be control rod sheath and joints, core supports, core restraint, etc. for which the required stiffness, high temperature strength, stress rupture life, or irradiation performance are not met by the existing engineered alloys. ${ }^{2}$ All designs considered in the U.S. (pebble bed design by Westinghouse and the prismatic reactor designs by AREVA and General Atomics) consider the use of $\mathrm{SiC} / \mathrm{SiC}$ composites for components in reactivity control system, such as the control rods and shutdown rods. This selection is motivated by the fact that $\mathrm{SiC} / \mathrm{SiC}$ is the only available material that can withstand the high fluence (up to $30 \mathrm{dpa})$ and temperature $\left(1100{ }^{\circ} \mathrm{C}\right.$ in normal conditions, $1600{ }^{\circ} \mathrm{C}$ in off-normal conditions) required for these components.

Table 1 Impurity content in helium-cooled high temperature reactors

\begin{tabular}{llccccccc}
\hline \hline & units & $\mathrm{H}_{2} \mathrm{O}$ & $\mathrm{H}_{2}$ & $\mathrm{CO}$ & $\mathrm{O}_{2}$ & $\mathrm{~N}_{2}$ & $\mathrm{CO}_{2}$ & $\mathrm{CH}_{4}$ \\
\hline \hline DRAGON, UK (1964-75) $^{4}$ & $\mathrm{~Pa}$ & 0.1 & 2 & 1.2 & $\mathrm{n} / \mathrm{a}$ & 0.3 & $<0.04$ & 0.3 \\
Peach Bottom, USA (1967-74) $^{5}$ & $\mathrm{ppmv}$ & 0.5 & 10 & 0.5 & $\mathrm{n} / \mathrm{a}$ & 0.5 & $<0.5$ & 1 \\
AVR, Germany (1967-88) $^{4}$ & $\mathrm{~Pa}$ & 3 & 30 & 10 & $\mathrm{n} / \mathrm{a}$ & $\mathrm{n} / \mathrm{a}$ & 10 & $\mathrm{n} / \mathrm{a}$ \\
Fort St. Vrain, USA (1976-79) $^{5}$ & $\mathrm{ppmv}$ & $<1$ & $2--7$ & $1-10$ & $\mathrm{n} / \mathrm{a}$ & $\mathrm{n} / \mathrm{a}$ & $0.5--3$ & $0.1--0.8$ \\
HTR-10, China (2003) $^{6}$ & $\mathrm{ppmv}$ & $<0.2$ & $<3$ & $<3$ & $\mathrm{n} / \mathrm{a}$ & $<1$ & $\mathrm{n} / \mathrm{a}$ & $<1$ \\
HTR-PM, China (project) $^{7}$ & $\mathrm{ppmv}$ & 2 & 30 & 30 & 0.2 & 2 & 6 & 5 \\
HTTR, Japan (1998-present) $^{8}$ & ppmv & $<0.2$ & $<3$ & $<3$ & $\mathrm{n} / \mathrm{a}$ & $<0.2$ & $<0.6$ & $<0.5$ \\
General Atomics (concept) $^{2}$ & ppmv & 0.5 & 3 & 2 & $\mathrm{n} / \mathrm{a}$ & 2 & 1 & 0.1 \\
\hline \hline
\end{tabular}

Different off-normal (accident) scenarios have been envisioned. Although not probable, the behavior of materials in those extreme conditions should be known. VHTR reactors are protected by passive safety features, and the most serious accident for this rector design is air-ingress followed by a large pipe break. Fast oxidation of graphite in the reflector and moderator would generate a large amount of heat that would increase the temperature of the core. However, various analysis results show that even under severe chemical reacting conditions, the maximum core temperature might rise up to $1430{ }^{\circ} \mathrm{C}$ but would not reach the maximum temperature criteria $\left(1600^{\circ} \mathrm{C}\right) .{ }^{9,10}$

Based on the above information, the environment conditions that must be analyzed for assessing the stability of $\mathrm{SiC} / \mathrm{SiC}$ composites in VHTR are as follows:

Normal operation conditions:

- helium coolant with ppm-range impurities $\left(\mathrm{H}_{2} \mathrm{O}, \mathrm{CO}_{2}, \mathrm{O}_{2}, \mathrm{H}_{2}, \mathrm{CH}_{4}\right)$ - see Table 1

- temperature $700-950{ }^{\circ} \mathrm{C}$

Off-normal conditions:

- air or water ingress

- temperature $\quad<1500{ }^{\circ} \mathrm{C}$

The general concern is about gas impurities with oxidizing character $\left(\mathrm{H}_{2} \mathrm{O}, \mathrm{CO}_{2}, \mathrm{O}_{2}\right)$ that may affect the interphase layer of $\mathrm{SiC} / \mathrm{SiC}$ composites. Water and oxygen, in particular, have several reaction channels with $\mathrm{SiC}$, depending on temperature and gas phase composition. Reducing impurities $\left(\mathrm{CO}, \mathrm{H}_{2}\right)$ 
are of little concern for the normal operation conditions. The helium coolant in HTGR and VHTR will have a slightly oxidizing character in order to protect metallic components against carburization and/or embrittlement However, at some extreme conditions (high pressures of $\mathrm{H}_{2}$ or $\mathrm{CO}$ ) gasification of SiC may also occur. A special case is the condition of low oxygen environment at high temperatures, as it is expected to be the gas coolant atmosphere in HTGR. The reactivity of various components in $\mathrm{SiC} / \mathrm{SiC}$ composites is presented in the next chapter. 


\section{OXIDATION OF SiC/SiC COMPONENTS}

Oxidation of all silicon-rich materials, either pure silicon or silicon-based ceramics, occurs according to the same basic mechanisms: in a plentiful supply of oxygen oxidation occurs with the formation of a passive, protecting silica $\left(\mathrm{SiO}_{2}\right)$ surface layer (passive oxidation); however, with a limited supply of oxidant, severe corrosion occurs through oxidative volatilization and release of $\mathrm{SiO}$ gas phase (active oxidation). This pattern will be discussed below, separately for each of the components of $\mathrm{SiC} / \mathrm{SiC}$ composites: monolithic crystalline $\mathrm{SiC}$ material, $\mathrm{SiC}$ fibers, and the interphase layer.

\subsection{OXIDATION OF MASSIVE SiC}

\subsubsection{Passive Oxidation in Presence of Oxygen}

Massive $\mathrm{SiC}$ oxidized in air at high temperatures produces a thin, adherent surface silica layer through the following reactions:

$$
\begin{aligned}
& \mathrm{SiC}_{(\mathrm{s})}+3 / 2 \mathrm{O}_{2(\mathrm{~g})}=\mathrm{SiO}_{2(\mathrm{~s})}+\mathrm{CO}_{(\mathrm{g})} \\
& \mathrm{SiC}_{(\mathrm{s})}+2 \mathrm{O}_{2(\mathrm{~g})}=\mathrm{SiO}_{2(\mathrm{~s})}+\mathrm{CO}_{2(\mathrm{~g})}
\end{aligned}
$$

The growth rate of the silica layer (in terms of the scale thickness, $x$, or mass gain) follows a linearparabolic law with two rate constants, $K_{P}$ and $K_{L}$, for the parabolic and linear regime:

$$
\frac{K_{P}}{x^{2}}+\frac{K_{L}}{x}=t+\tau
$$

where $\tau$ is a constant that accounts for the initial scale thickness. ${ }^{11}$ The parabolic term capturing the diffusion-limited kinetics becomes the main contributor at long oxidation times while the linear term represents reaction-limited kinetics and is important during early stages. Formation of the passive $\mathrm{SiO}_{2}$ layer explains the outstanding oxidation resistance of silicon-based ceramics.

Oxidation rates of crystalline $\alpha-\mathrm{SiC}$ are limited by the transfer of oxygen through the scale. Below about $1400{ }^{\circ} \mathrm{C}$ oxygen permeates in molecular form, and the process is independent of oxygen pressure, $P_{\mathrm{O} 2}$ (activation energy $E_{a}=120 \mathrm{~kJ} / \mathrm{mol}$ ). At higher temperatures, atomic oxygen permeates the scale and the rate is proportional with $\left(P_{\mathrm{O} 2}\right)^{n}$. A higher activation energy $(200-300 \mathrm{~kJ} / \mathrm{mol})$ reflects the energy needed to dissociate the oxygen molecules. ${ }^{12}$

Polycrystalline $\mathrm{SiC}$ follows a similar oxidation mechanism, but the characteristics vary depending on the $\mathrm{SiC}$ purity and the degree of crystallization. Activation energies reported by various authors are spread from 120 to $420 \mathrm{~kJ} / \mathrm{mol}$. Additives in $\mathrm{SiC}$ and impurities in the gas phase increase, in general, the rate of

oxidation. Crystallization of silica changes the oxidation kinetics by changing the diffusion mechanism of $\mathrm{CO}$ and oxygen. ${ }^{13}$

\subsubsection{Active Oxidation at Low Oxygen Concentrations}

In an environment with low oxidizing potential, below a critical $P_{\mathrm{O} 2}$, silica is no longer stable, as a new oxidation reaction replaces the reaction paths illustrated by equations (2) and (3): 


$$
\mathrm{SiC}_{(\mathrm{s})}+\mathrm{O}_{2(\mathrm{~g})}=\mathrm{SiO}_{(\mathrm{g})}+\mathrm{CO}_{(\mathrm{g})}
$$

Conversion of $\mathrm{SiC}$ into gaseous products is recognized by the accompanying mass loss. The transition between active and passive oxidation has been discussed by several investigators. ${ }^{14}$ The rate and the transition temperature depend on factors such as $\mathrm{SiC}$ purity, temperature, gas flow composition and velocity, total pressure, and oxygen partial pressure. ${ }^{15,16,17}$

\subsubsection{Effect of Water Vapor and Other Gas Environments}

The passive mode of oxidation by water vapor occurs through the following reactions:

$$
\begin{array}{lr}
\mathrm{SiC}_{(\mathrm{s})}+2 \mathrm{H}_{2} \mathrm{O}_{(\mathrm{g})} \rightarrow \mathrm{SiO}_{2(\mathrm{~s})}+\mathrm{CH}_{4(\mathrm{~g})} & \text { at } T<1400{ }^{\circ} \mathrm{C} \\
\mathrm{SiC}_{(\mathrm{s})}+3 \mathrm{H}_{2} \mathrm{O}_{(\mathrm{g})} \rightarrow \mathrm{SiO}_{2(\mathrm{~s})}+\mathrm{CO}_{2(\mathrm{~g})}+3 \mathrm{H}_{2(\mathrm{~g})} & \text { at } T>1400{ }^{\circ} \mathrm{C}
\end{array}
$$

Presence of water vapor in oxygen (or air) enhances the rate of passive oxidation, from about 2-3 times (when $10 \% \mathrm{H}_{2} \mathrm{O}$ is added to oxygen) to about 10-20 times (when comparing oxidation in steam versus dry oxygen). ${ }^{18}$ The rate enhancement is explained by water having higher affinity to silica than oxygen, and thus higher permeability through the scale $\mathrm{SiO}_{2}$ layer. In addition, water can break Si-O bonds, which enhances diffusion. For these reasons, the linear term dominates in the linear-parabolic kinetics shown by equation (4) above. ${ }^{19}$

In a water-rich atmosphere (steam), gasification of the protective silica layer may occur with formation of gaseous $\mathrm{SiO}(\mathrm{OH})_{\mathrm{x}}$ volatile species, according to the following reactions:

$$
\begin{aligned}
& \mathrm{SiO}_{2(\mathrm{~s})}+\mathrm{H}_{2} \mathrm{O}_{(\mathrm{g})}=\mathrm{SiO}(\mathrm{OH})_{2(\mathrm{~g})} \\
& \mathrm{SiO}_{2(\mathrm{~s})}+2 \mathrm{H}_{2} \mathrm{O}_{(\mathrm{g})}=\mathrm{SiO}(\mathrm{OH})_{4(\mathrm{~g})}
\end{aligned}
$$

for which the rate is proportional with $P_{\mathrm{H} 2 \mathrm{O}}$ and $\left(P_{\mathrm{H} 2 \mathrm{O}}\right)^{2}$ respectively. Therefore the higher the moisture content, the more important is the weight loss of the passive $\mathrm{SiO}_{2}$ layer. ${ }^{20}$

In a mixed $\mathrm{H}_{2} \mathrm{O} / \mathrm{H}_{2}$ environment, oxidation of $\mathrm{SiC}$ follows an active mechanism at $1300-1400{ }^{\circ} \mathrm{C}$ according to the following reactions:

$$
\begin{aligned}
& \mathrm{SiC}_{(\mathrm{s})}+\mathrm{H}_{2} \mathrm{O}_{(\mathrm{g})}=\mathrm{SiO}_{(\mathrm{g})}+\mathrm{CH}_{4(\mathrm{~g})} \\
& \mathrm{SiC}_{(\mathrm{s})}+2 \mathrm{H}_{2} \mathrm{O}_{(\mathrm{g})}=\mathrm{SiO}_{(\mathrm{g})}+\mathrm{CO}_{(\mathrm{g})}+2 \mathrm{H}_{2(\mathrm{~g})}
\end{aligned}
$$

In presence of high $P_{\mathrm{H} 2}$ gasification may occur through reduction of the silica layer, according to:

$$
\mathrm{SiO}_{2(\mathrm{~s})}+\mathrm{H}_{2(\mathrm{~g})}=\mathrm{SiO}_{(\mathrm{g})}+\mathrm{H}_{2} \mathrm{O}_{(\mathrm{g})}
$$

Conditions of active oxidation at low oxygen partial pressure may also occur in presence of $\mathrm{CO}_{2} / \mathrm{CO}$ mixtures. It was reported that active oxidation occurs at $P_{\mathrm{CO} 2} / P_{\mathrm{CO}}$ ratios in the range of $10^{-4}$ to $10^{-1}$ and the mass loss of $\mathrm{SiC}$ is maximum at intermediate ratios. ${ }^{21}$ Active volatilization of $\mathrm{SiC}$ may also occur at low partial pressures of $\mathrm{CO}_{2}{ }^{22}$ 


\subsection{OXIDATION OF SiC MATRIX}

In order to understand the behavior of $\mathrm{SiC} / \mathrm{SiC}$ composites in an oxidative atmosphere, the knowledge of oxidation kinetics of the $\mathrm{SiC}$ matrix (formed under specific conditions) is as important as the knowledge of oxidation kinetics of crystalline $\mathrm{SiC}$ materials or of $\mathrm{SiC}$ fibers. A comparison between the oxidation kinetics of $\mathrm{SiC}$ deposits formed by CVI from $\mathrm{CH}_{2} \mathrm{SiCl}_{3} / \mathrm{H}_{2}$ mixture and that of pure silicon (selected as standard) and other $\mathrm{SiC}$ ceramics showed that the behavior of CVI $\beta$-SiC under pure oxygen follows the characteristics of passive oxidation at temperatures in the $900-1500$ ${ }^{\circ} \mathrm{C}$ range. ${ }^{23}$ The surface layer grows according to the parabolic law, and the protective silica layer is amorphous except after treatment at $1500{ }^{\circ} \mathrm{C}$. Figure 1 shows crystobalite crystals formed from $\mathrm{SiC}$ (CVI)

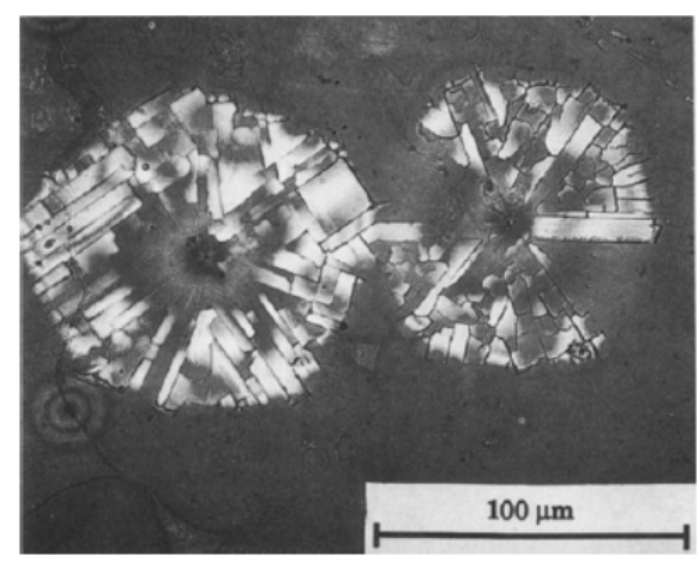

Fig. 1: Optical micrographs showing development of crystobalite at the surface of $\mathrm{SiC}$ sample treated at 1500 $\mathrm{oC}$ in a flow of pure oxygen. From reference ${ }^{23}$. maintained at $1500{ }^{\circ} \mathrm{C}$ in a flow of pure oxygen at $100 \mathrm{kPa}^{23}$

In conditions of VHTR or GFR, the partial pressure of oxygen in helium coolant is much lower, and the investigation of passive to active transition at much lower $P_{\mathrm{O} 2}$ was needed for understanding of $\mathrm{SiC}$ behavior at the high temperatures that may occur in accident conditions. Charpentier et al. measured oxidation kinetics of sintered $\alpha$ $\mathrm{SiC}$ and $\mathrm{CVD} \beta$-SiC at oxygen pressures between 0.2 and $100 \mathrm{~Pa}$ in $\mathrm{He}$ (total pressure $100 \mathrm{kPa}$ ) and a broad temperature range. ${ }^{3,24}$ The $\alpha-\mathrm{SiC}$ was obtained from Boostec (France) and was processed by pressureless sintering at $\sim 2000{ }^{\circ} \mathrm{C}$ with $\mathrm{B}_{4} \mathrm{C}$ as additive. ${ }^{3}$ The $\beta-\mathrm{SiC}$ was obtained from Rohm \& Haas (USA) and was processed by

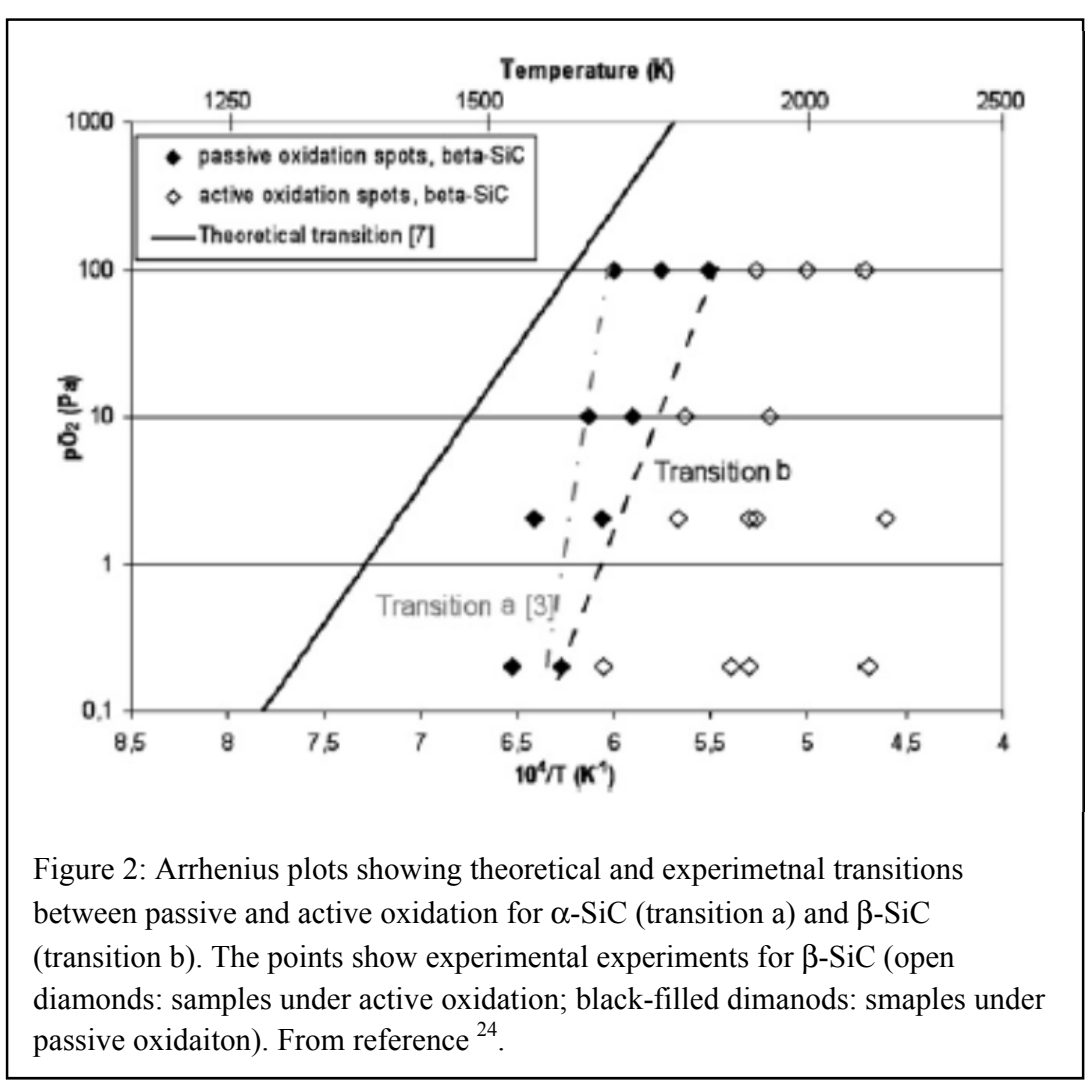

CVD at $1200-1300{ }^{\circ} \mathrm{C}^{24}$ The authors cited above found that the transition between passive and active 
oxidation regime occurs at higher temperatures for $\beta$-SiC than for $\alpha-\mathrm{SiC}$, and the mas loss rate of $\beta$-SiC is lower than the one measured for $\alpha$-SiC on the common temperature range investigated (up to $1800{ }^{\circ} \mathrm{C}$ ). Figure 2 show theoretical and experimental transitions observed for the two SiC allotropes. Oxygen partial pressure has no effect on the mass loss rate of $\beta$-SiC in active oxidation conditions up to $P_{\mathrm{O} 2}=10$ $\mathrm{Pa}$ in this temperature range, contrary to the behavior of $\alpha-\mathrm{SiC}$. This is an important conclusion, showing that high purity helium is not necessary to prevent $\beta$-SiC from severe oxidation up to $1800{ }^{\circ} \mathrm{C}$. This temperature is way above the normal operation range of VHTR and GFR, and is improbable even in severe accident conditions. ${ }^{9}$ Severe damage of $\beta$-SiC occurred at $\sim 2000{ }^{\circ} \mathrm{C}$ and $P_{\mathrm{O} 2}=2 \mathrm{~Pa}$ caused by combined active oxidation and sublimation of $\mathrm{SiC}$. At these extreme conditions, the mass loss rate was $30 \mathrm{mg} \mathrm{cm}^{-2} \mathrm{~h}^{-1}$.
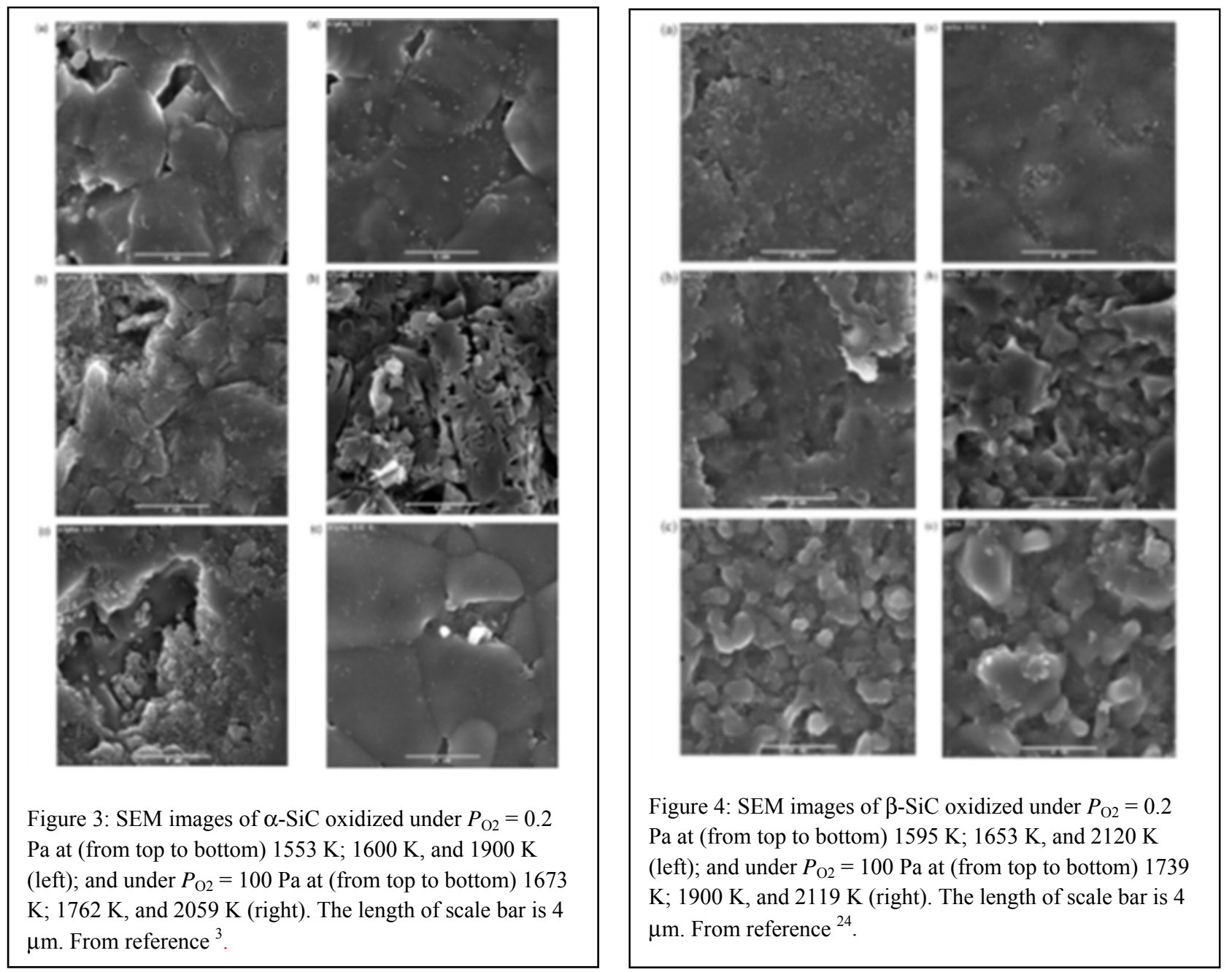

Figures 3 and 4 show selected SEM images ${ }^{3,24}$ of oxidized surfaces of sintered $\alpha$ - and crystalline $\beta$ $\mathrm{SiC}$ exposed to 0.2 and $100 \mathrm{~Pa}$ oxygen in helium. The temperatures where active to passive oxidation 
occurs vary, depending on the crystalline form and the oxygen pressure. These images correspond to several experimental data points shown in Fig. 2.

\subsection{OXIDATION OF SiC FIBERS}

Oxidation of $\mathrm{SiC}$ fibers follows the general behavior of pure (crystalline) $\mathrm{SiC}$, and exhibits the same transition between passive and active oxidation. However, SiC fibers may also contain oxycarbide (first generation), free carbon (second generation) or additives (some of the third generation) which may influence the oxidation properties. ${ }^{13}$

Oxidation at $1500{ }^{\circ} \mathrm{C}$ of Nicalon CG fibers (Si-C-O system, first generation) was active at $100 \mathrm{~Pa} \mathrm{O}_{2}$ and transitioned to passive oxidation at $250 \mathrm{~Pa}$. At higher $P_{\mathrm{O} 2}$ oxidation was passive, with mass gain caused by the growth of silica layer. This impermeable silica layer formed by passive oxidation decreased thermal decomposition by preventing gaseous products from escaping the fiber. ${ }^{25}$

Passive oxidation of Hi-Nicalon fibers (second generation) followed a parabolic law, with radial silica growth. The active to passive transition occurred at $10-25 \mathrm{~Pa}$ at $1500{ }^{\circ} \mathrm{C}$. The silica layer improved the high temperature behavior. Hi-Nicalon fibers did not keep any residual strength when exposed to Ar at $1500{ }^{\circ} \mathrm{C}$, but pre-oxidation at 800 $1500{ }^{\circ} \mathrm{C}$ enabled a quite high tensile strength. ${ }^{26}, 27$

In the third generation fibers (stoichiometric), Hi-Nicalon S, showed the transition from passive to active oxidation at $1500{ }^{\circ} \mathrm{C}$ under very low partial pressure of oxygen, and Tyranno SA fibers did not undergo active oxidation above $1 \mathrm{~Pa} \mathrm{O}_{2}$. Thus, the resistance against active oxidation has continuously improved from first generation fibers to the third (Fig. 5). ${ }^{25}$

When $20 \mathrm{kPa}$ water was present in

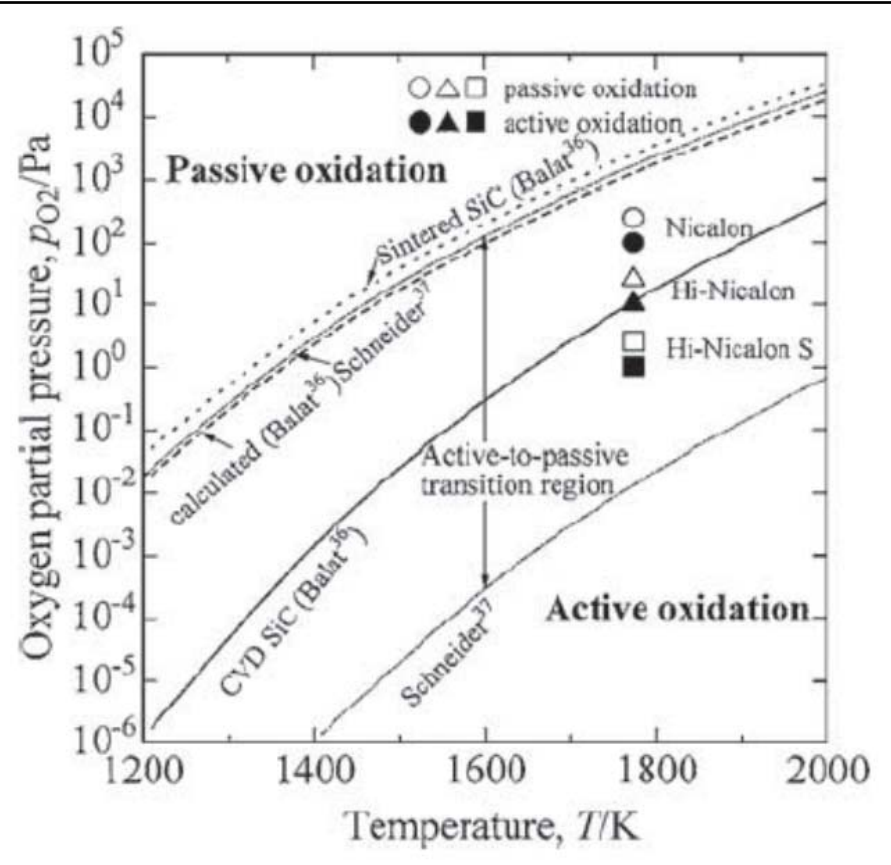

Figure 5: Oxygen partial pressure for active-to-passive oxidation transition of $\mathrm{SiC}$ as a function of temperatures, showing continuous improvement of oxidation resistance over three generations of $\mathrm{SiC}$ fibers (Nicalon, Hi-Nicalon, and Hi-Nicalon S). From reference ${ }^{25}$. $\mathrm{O}_{2}$-Ar mixtures $\left(20 \mathrm{kPa} \mathrm{O}_{2}\right)$, oxidation rates of Hi-Nicalon fibers increased dramatically (about 20 times at $1000{ }^{\circ} \mathrm{C}$ ) as in the case of massive $\mathrm{SiC}$, and the activation energy decreased. This shows that water can act as the main oxidizing agent according to reactions $(8-10)$ above. ${ }^{28}$ 


\subsection{OXIDATION OF THE INTERPHASE}

All carbons, including pyrocarbon, are sensitive to oxidation by oxygen, carbon dioxide and water, according to the following reactions:

$\mathrm{C}_{(\mathrm{s})}+\mathrm{O}_{2(\mathrm{~g})}=\mathrm{CO}_{2(\mathrm{~g})}$

$\mathrm{C}_{(\mathrm{s})}+1 / 2 \mathrm{O}_{2(\mathrm{~g})}=\mathrm{CO}_{(\mathrm{g})}$

$\mathrm{C}_{(\mathrm{s})}+\mathrm{CO}_{2(\mathrm{~g})}=2 \mathrm{CO}_{(\mathrm{g})}$

$\mathrm{C}_{(\mathrm{s})}+\mathrm{H}_{2} \mathrm{O}_{(\mathrm{g})}=\mathrm{CO}_{(\mathrm{g})}+\mathrm{H}_{2(\mathrm{~g})}$

However, pyrocarbon is known to have higher chemical resistance to oxidation than other forms of carbon. The lower oxidation rates observed by pyrocarbon are caused by kinetic factors (limited in-pore diffusion caused by extremely low porosity). The SEM image in Fig. 6 show the cross-end of a T300 carbon fiber tows (not heat-treated) infiltrated with a pyrocarbon interphase after mild oxidation at $550{ }^{\circ} \mathrm{C}$ in pure oxygen. The superior resistance of pyrocarbon is evident. However, when the same carbon fibers were heat-treated at $1600{ }^{\circ} \mathrm{C}$ to improve their structural order, they showed similar oxidation behavior as the pyrocarbon interphase. ${ }^{28}$

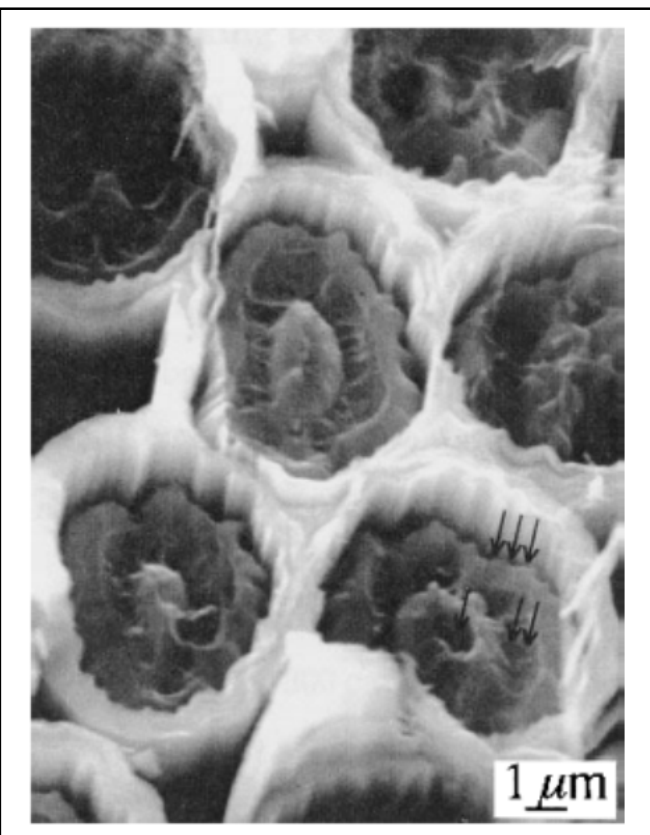

Figure 6: SEM image of pyrocarbon-infiltrated carbon fiber tow showing that pyrocarbon has higher oxidation resistance. From reference ${ }^{28}$. 


\section{THERMAL AGEING AND OXIDATION OF SiC/SiC COMPOSITES}

Fibers and interphase layers play a major role in the mechanical properties of composites. Because composites are designed to form micro-cracks upon excessive loading, and fibers and interphase are sensitive to oxidation, oxidizing species can access the inner components and oxidation gaseous products can escape, causing weight loss and structural damage in composites. Improving the lifetime of composites requires developing protection methods to mitigate fibers thermal instability and the interphase preferential oxidation. ${ }^{13}$

\subsection{THERMAL AGEING}

The thermal stability in vacuum of $\mathrm{SiC} / \mathrm{SiC}$ composites prepared with chemical vapor infiltration has improved considerably from first to the third generation of $\mathrm{SiC}$ fibers. For example, a parallel examination of structural and mechanical properties of composites prepared from commercial grade Nicalon, Hi-Nicalon, and stoichiometric Hi-Nicalon type S after heat treatment in vacuum (1 hour at 1000 $-2000{ }^{\circ} \mathrm{C}$ ) has shown important stability differences. ${ }^{29}$

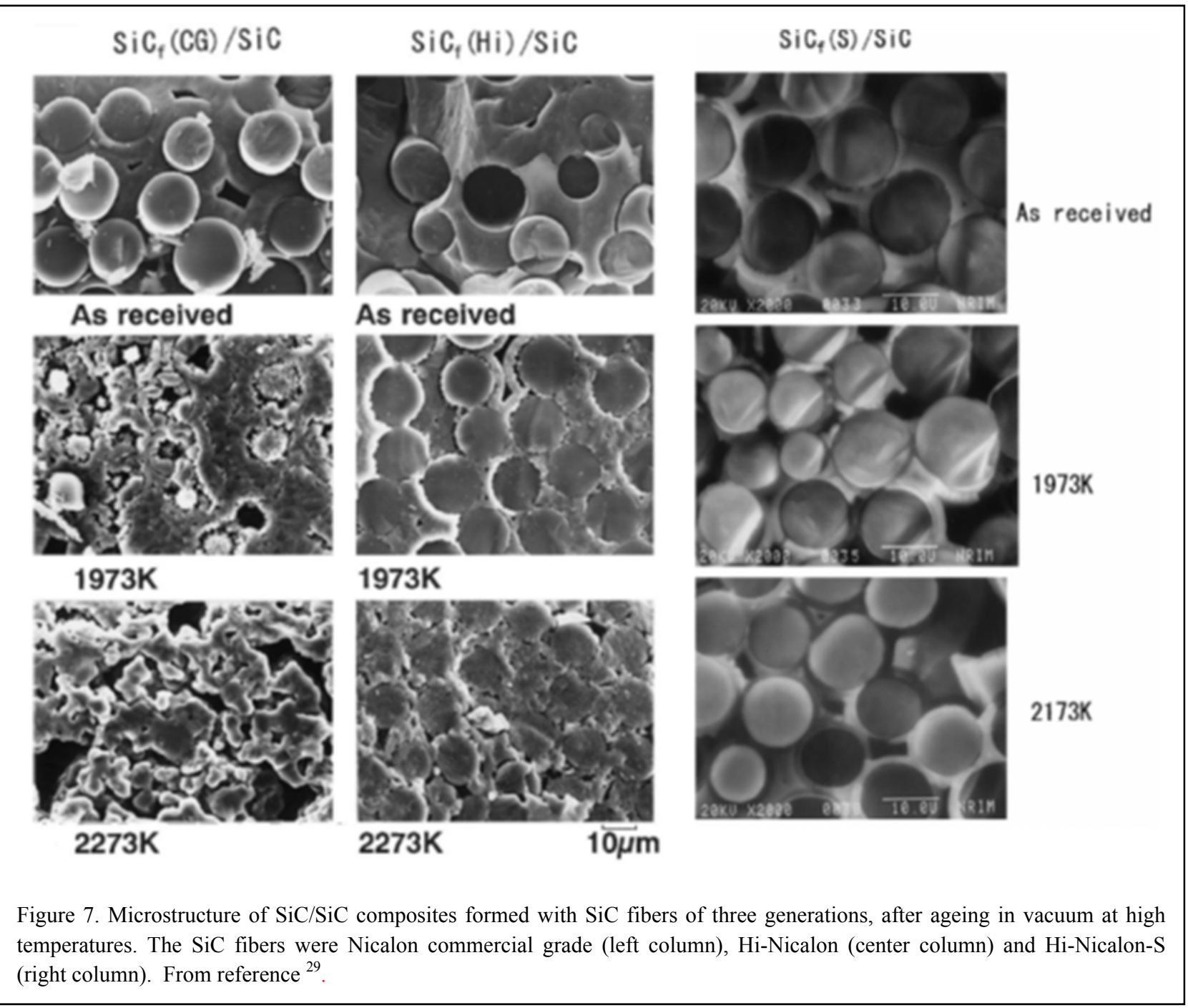


The oxygen-rich Nicalon fibers of the first generation lost volatile $\mathrm{SiO}$ in the gas phase according to the reaction shown below, starting from about $1400{ }^{\circ} \mathrm{C}$ :

$\left(\mathrm{SiC}, \mathrm{SiC}_{2 \mathrm{x}} \mathrm{O}_{1-\mathrm{x}}\right) \rightarrow \mathrm{w} \mathrm{SiC}_{(\mathrm{s})}+\mathrm{x} \mathrm{C}_{(\mathrm{s})}+\mathrm{y} \mathrm{SiO}_{(\mathrm{g})}\left[+\mathrm{zC}_{(\mathrm{s})}\right]$

The oxycarbide $\mathrm{SiC}_{2 \mathrm{x}} \mathrm{O}_{1-\mathrm{x}}$ decomposed completely above $1700{ }^{\circ} \mathrm{C}$, which caused a drop in flexural strength and fracture toughness. Significant growth of $\mathrm{SiC}$ grains occurred simultaneously, ${ }^{30}$ as a side reaction between $\mathrm{SiO}$ in the gas phase and the carbon interphase:

$\mathrm{SiO}_{(\mathrm{g})}+2 \mathrm{C}_{(\mathrm{s})}=\mathrm{SiC}_{(\mathrm{s})}+\mathrm{CO}_{(\mathrm{g})}$

In the same conditions, the second generation fiber Hi-Nicalon experienced just a slight degradation of bending properties, ${ }^{29}$ caused by the reaction

$\mathrm{SiC}_{1+\mathrm{x}(\mathrm{s})}+\mathrm{O}_{\text {trace }(\mathrm{g}, \mathrm{s})} \rightarrow \mathrm{SiC}_{(\mathrm{s})}+\mathrm{CO}_{(\mathrm{g})}$

In contrast, the composite with the stoichiometric Hi-Nicalon S fibers (third generation) suffered no significant change in bending properties after thermal treatment. The composites made with these latter fibers did not suffer any apparent deterioration after heat treatment up to $1900{ }^{\circ} \mathrm{C}$ in vacuum. The microstructural changes suffered by the three types of composites are illustrated by the microscopy images in Fig. 7. ${ }^{29}$ Composites made with Tyranno-SA fibers and CVI SiC matrix maintained high strength up to $1700{ }^{\circ} \mathrm{C}$. Above this temperature, the strength decreased because of CVI matrix recrystallization and degradation of the Tyranno-SA fibers. ${ }^{31}$

\subsection{OXIDATION}

\subsubsection{Effect of Oxygen}

When $\mathrm{SiC} / \mathrm{PyC} / \mathrm{SiC}$ composites with machined surfaces or open cracks are exposed to environmental conditions that promote passive oxidation of $\mathrm{SiC}$ (e.g. $100 \mathrm{kPa} \mathrm{O}, 700{ }^{\circ} \mathrm{C}<\mathrm{T}<1400{ }^{\circ} \mathrm{C}$ ) the attack on the composite is initiated at the interphase layer, which is sensitive to gasification according to equations (13) - (15). It is believed ${ }^{32}$ that the mechanism involves the steps of (1) oxidation of carbon interphase by direct reaction with oxygen and formation of a pore in the structure; (2) oxygen and carbon oxides diffusion along the pore; (3) reaction of oxygen with the pore walls leading to the growth of a silica layer on both the fiber and the matrix, according to reactions (2) and (3) above. If the interphase is thin enough, silica is able to seal the pore and the active oxidation process ends. However, if the pyrocarbon interphase layer is thicker, the pore formed is larger and the reactions (13) - (15) proceed until the carbon layer is entirely consumed.

Oxidation in air at intermediate temperatures $\left(600-800{ }^{\circ} \mathrm{C}\right)$ was shown to consume the interphase $\mathrm{PyC}$ layer, and cause stronger bonding between fibers and matrix by the $\mathrm{SiO}_{2}$ layer formed at $800{ }^{\circ} \mathrm{C}$. Both effects lead to decreased cyclic fatigue life, but the strong fiber-matrix bonding by the silica layer leads to the shortest fatigue life. ${ }^{33}$ 
When exposed to oxygen at $1000{ }^{\circ} \mathrm{C}, \mathrm{SiC} / \mathrm{PyC} / \mathrm{SiC}$ composites experience first a mass loss attributed to oxidation of the pyrocarbon layer accompanied by recession of the interphase, followed by a parabolic weight gain that indicates development of the silica layer. The recession of thick interphase layer occurs between $800-1200{ }^{\circ} \mathrm{C}$ after either a linear or parabolic kinetic law, where the reaction order for oxygen is between 0.5 and $1 .^{13}$ Gasification of the interphase impacts considerably the mechanical strength of the composite and cause embrittlement. Comparing TGA curves during oxidation with in situ Young's modulus measurements of a $\mathrm{SiC}_{\mathrm{f}}(\mathrm{CG}) / \mathrm{PyC} / \mathrm{CVI}-\mathrm{SiC}$ composite revealed that interphase recession causes a sharp decrease of modulus, which may recover eventually if the newly formed silica layer closes the gap between fibers and matrix. ${ }^{34}$

Degradation of $\mathrm{SiC} / \mathrm{SiC}$ composites follows a different mechanism when exposure to high temperatures occurs in air or in vacuum. ${ }^{35}$ Figure 8 shows weight changes versus exposure time at different temperatures. In this example, the fiber produced by Ube Companies was of ZMI type, with a non-stoichiometric composition described as $\mathrm{SiZr}_{<0.01} \mathrm{C}_{1.44} \mathrm{O}_{0.32}$. The large weight loss observed in vacuum at $1200-1400{ }^{\circ} \mathrm{C}$ is caused by decomposition of the fiber and loss of gaseous products, $\mathrm{SiO}_{(\mathrm{g})}$ and $\mathrm{CO}_{(\mathrm{g})}$. In air, a slight weight gain is observed which indicates formation of silica protective layer. The fracture mechanism was also different: the vacuum-exposed composite showed only the fiber-pullout type fracture, while the fracture mode of air-exposed composites changed with the progress of oxidation from the fiber-pullout type to the nonfiber-pullout type. $^{35}$

Nearly stoichiometric $\mathrm{SiC}$ fibers of the third generation are more stable than those of generation one or two. The oxidation behavior in air of Tyrannohex ${ }^{\mathrm{TM}}$ composite containing Tyranno ${ }^{\mathrm{TM}}$ Si-C-Al-O fibers is different from that of Al-free fibers, which is an effect of the different crystallinity of the $\mathrm{SiO}_{2}$ scale. ${ }^{36}$ During heating, an
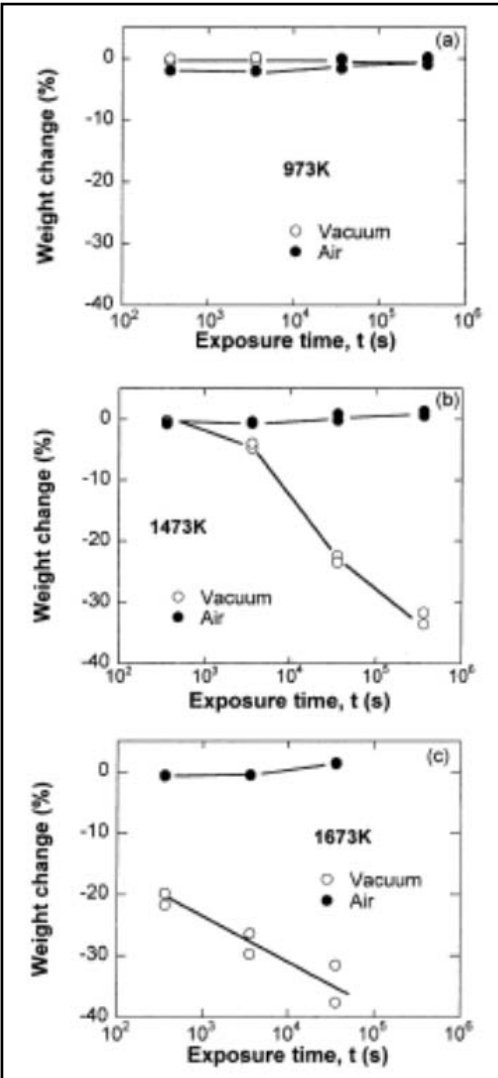

Figure 8 Composite weight changes caused by exposure in vacuum and in air at 700,1200 , and $1400{ }^{\circ} \mathrm{C}$. From reference ${ }^{35}$. amorphous $\mathrm{SiO}_{2}$ scale was formed which hosted gas bubbles generated by the gaseous products of oxidation. This caused a large weight loss after $4000 \mathrm{~h}$ exposure to $1500{ }^{\circ} \mathrm{C}$ in spite of the conditions favoring passive oxidation. The large weight loss was caused by destruction of the oxidation-protective scale by bursting $\mathrm{SiO}_{2}$ bubbles, along with higher diffusivity of oxygen in amorphous $\mathrm{SiO}_{2}$ scale containing aluminum ions.

Controlling the matrix crystallinity in $\mathrm{SiC} / \mathrm{SiC}$ composites made with third generation fibers (Tyranno ${ }^{\mathrm{TM}} \mathrm{SA}$ ) by the polymer impregnation and pyrolysis (PIP) method showed good results not only on mechanical properties, but also on oxidation resistance in air. ${ }^{37}$ The improvement was obtained through reduction of impurity content in the matrix and better organization of the crystal structure through annealing in argon at $1500-1700{ }^{\circ} \mathrm{C}$. Oxidation resistance was improved by the two-layered interphase $(100 \mathrm{~nm}$ PyC and $500 \mathrm{~nm} \mathrm{SiC})$. The superior flexural properties achieved by this treatment did not significantly degrade in air up to $1000{ }^{\circ} \mathrm{C}$ and mechanical properties remained stable up to $1300{ }^{\circ} \mathrm{C}$ in air. Conventional $\mathrm{SiC} / \mathrm{SiC}$ composites showed a slight reduction of flexural strength in the same conditions, 
caused by oxidation of impurities in constituents, such as the Tyranno-LoxM fiber with about 10 wt $\%$ oxygen. ${ }^{37}$

\subsubsection{Effect of Water}

The effect of water on $\mathrm{SiC} / \mathrm{SiC}$ composites was studied intensively in relation with the use of these materials in gas turbines where they are exposed to high temperature steam. Oxidation of $\mathrm{SiC}$ by steam according reactions (6) and (7) above forms a $\mathrm{SiO}_{2}$ layer. In presence of $\mathrm{H}_{2} \mathrm{O}$, however, this layer no longer protects the underlying $\mathrm{SiC}$ fiber and gasification continues according to reactions (8) and (9) above, controlled by the diffusion of volatile species $\mathrm{Si}-\mathrm{O}_{\mathrm{x}}-\mathrm{H}_{\mathrm{y}(\mathrm{g})}$ through a porous boundary layer. This is illustrated by the electron microscopy images presented in Figure 9, which also compare the surface of $\alpha-$ and $\beta$-SiC after exposure to high pressure steam in air, or dry air only. ${ }^{38}$
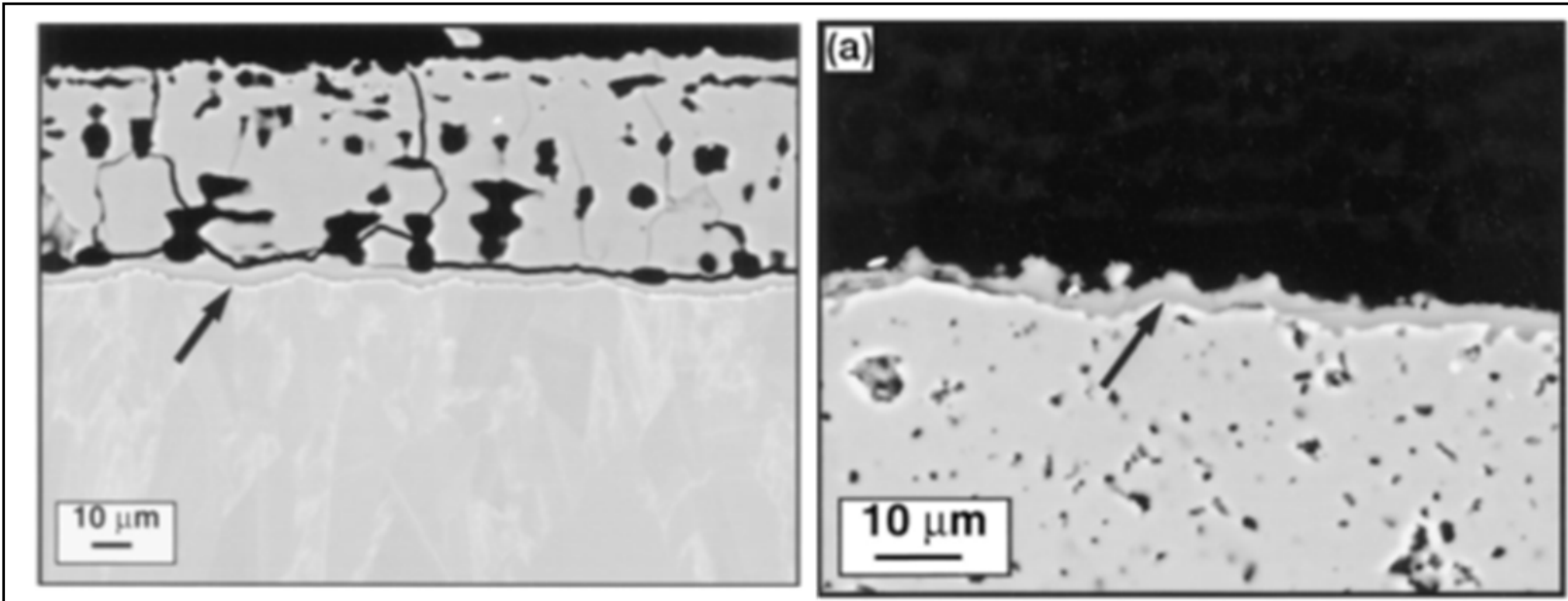

Figure 9: (Left): Typical silica scale morphology observed for CVD $\beta$-SiC after $500 \mathrm{~h}$ exposure to 10 bar air $+\mathrm{H}_{2} \mathrm{O}$ at $1200{ }^{\circ} \mathrm{C}$; (Right): Silica scale on sintered $\beta$-SiC after $100 \mathrm{~h}$ exposure to10 bar of (a) air and (b) air $+\mathrm{H}_{2} \mathrm{O}$ at $1200^{\circ} \mathrm{C}$. The arrows show the dense silica layer. Only this layer was formed when no $\mathrm{H}_{2} \mathrm{O}$ was present. From reference ${ }^{38}$.

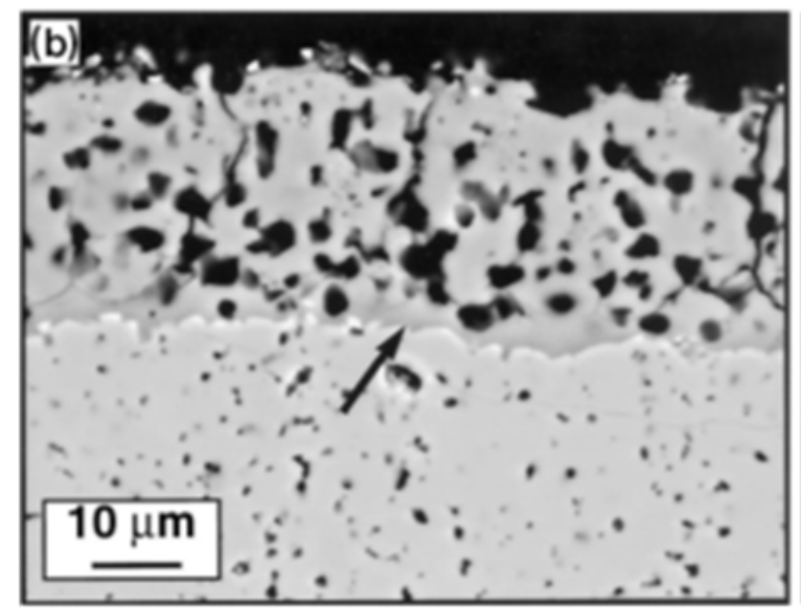

The same mechanism applies to $\mathrm{SiC} / \mathrm{SiC}$ composites. Oxidation of $1 \mathrm{D} \mathrm{SiC} / \mathrm{SiC}$ composites is enhanced when water is present in the oxidant gas. Compared with oxidation in dry air at $1520{ }^{\circ} \mathrm{C}$, oxidation in air saturated with water vapor at $25{ }^{\circ} \mathrm{C}$ is up to $50 \%$ higher. Even when oxygen is not present 
in the gas phase, water alone causes oxidation. Thus, oxidation of the same $1 \mathrm{D} \mathrm{SiC} / \mathrm{SiC}$ composite in argon saturated at $25{ }^{\circ} \mathrm{C}$ with water vapor was reported to cause half of the oxidation effects observed in dry air. ${ }^{39}$

A similar result was obtained by comparing the behavior of $\mathrm{SiC} / \mathrm{PyC} / \mathrm{SiC}$ composites (made with HiNicalon ${ }^{\mathrm{TM}}$ fiber and CVD SiC matrix) during oxidation in dry air and in a combustion gas containing 13 $\% \mathrm{H}_{2} \mathrm{O}$ and $33 \% \mathrm{CO}_{2} \cdot{ }^{40}$ Compared with air, the larger amount of water in combustion gas changed the oxidation mechanism from diffusion-controlled to reaction rate-controlled, and silica formation in water rich combustion gas was faster. Consequently, the oxidation channel could be sealed much earlier and the PyC interphase was oxidized less. However, because the oxidation consumed the interphase and weakened the interface with both the matrix and the fiber, the fracture displacement and the fracture work were greatly increased after oxidation in combustion gas, compared with oxidation in dry air. ${ }^{40}$ The oxidation resistance of $3 \mathrm{D} \mathrm{SiC} / \mathrm{SiC}$ composites $\left(\mathrm{Nicalon}^{\mathrm{TM}}\right.$ ) was always higher than that of $2 \mathrm{D} \mathrm{C} / \mathrm{SiC}$ composites (T-300, Toray) in the combustion environment. ${ }^{41}$

\subsubsection{Environmental Effects on Fatigue Behavior}

It is known that the macroscopic mechanical behavior of ceramic matrix composites is controlled not only by the individual failure of their constituents (fibers, matrix) but also by the interaction between constituents at the fiber-matrix interface. That is the reason why these composites exhibit a non-brittle mechanical behavior, although the constituents are brittle. This phenomenon is caused by the friction between fibers and matrix during sliding of fibers in the matrix. Changes in the microstructure of constituents, or in the interphase, may modify the interfacial shear stress. Such changes can be induced by thermal instability or by local chemical changes (oxidation), and they are reflected in the mechanical hysteresis during cyclic fatigue tests. ${ }^{42}$

For example, Figure 10 compares experimental evolution of stress/strain loops under tension/compression cyclic loading at room temperatures of a cross-weave $\mathrm{SiC} / \mathrm{SiC}$ composite (unprotected against oxidation (2D SiC/SiC GS4C, Nicalon fibers) provided by the Société Européenne de Propulsion (France) in two different conditions: as received and after vacuum ageing of $50 \mathrm{~h}$ at $800{ }^{\circ} \mathrm{C}$. In the as-received specimen, the mechanical hysteresis increases continuously during the cyclic fatigue test, and the tensile elastic modulus decreases continuously, while the compressive mean elastic modulus is constant. After ageing in vacuum, the cyclic fatigue tests show an increase followed by decrease of the mechanical hysteresis, accompanied by an increase of tensile mean elastic modulus which approaches and reaches the value of the compressive mean elastic modulus. These changes suggest that vacuum heating lowers the initial interfacial shear stress due to chemical reactions at the interface, possibly because of residual oxygen diffusion from the Nicalon $\mathrm{SiC}$ fibers to the pyrocarbon interphase. ${ }^{42}$ 


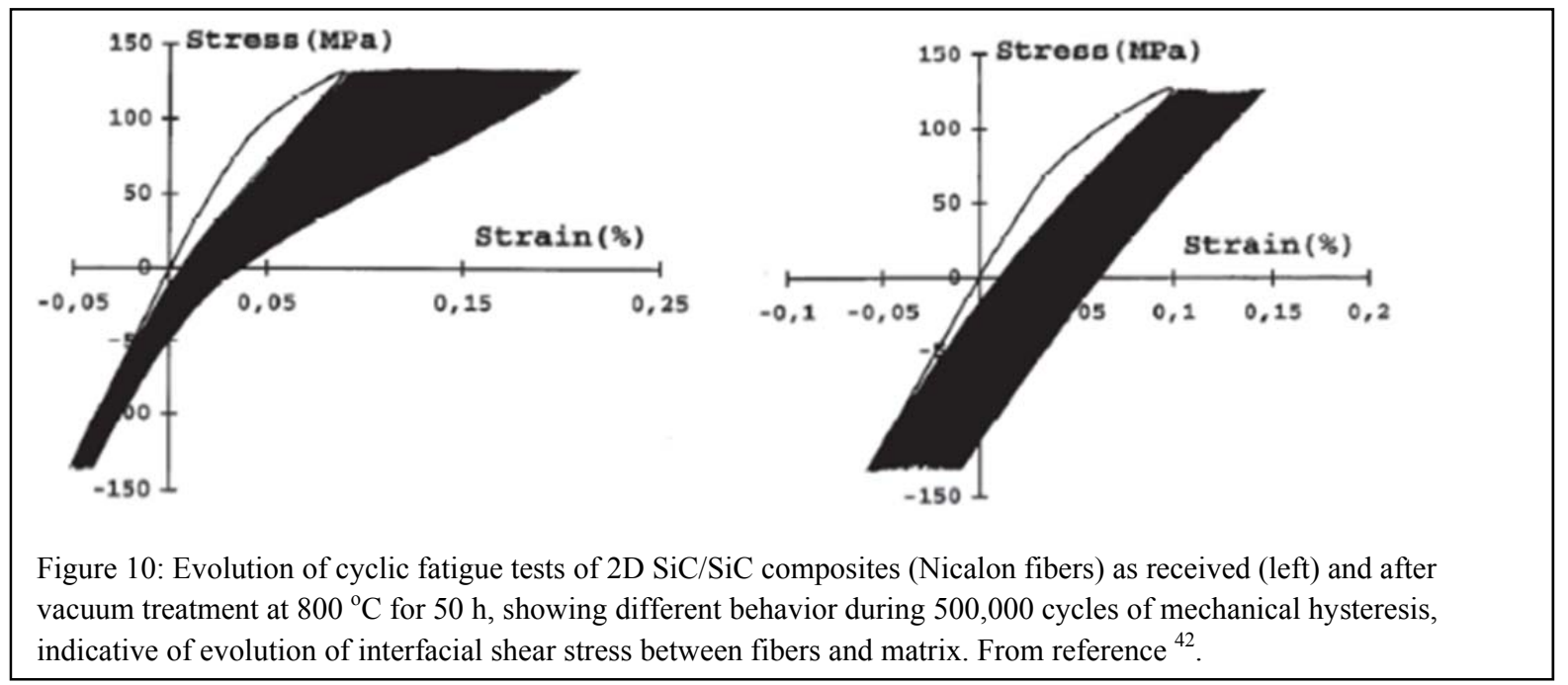

Mechanical stability of $\mathrm{SiC} / \mathrm{SiC}$ composites under cyclic loading in oxidizing environments is important in a multitude of applications where these composites are used, such as structural components in turbine engines of hypersonic flight vehicles, or in spacecraft reentry thermal protection systems. These advanced applications in aero- and space industries motivated recent interest on tension/compression fatigue at high temperature in air and steam environments. ${ }^{43,44}$ The composites were comprised of $\mathrm{Hi}$ Nicalon ${ }^{\mathrm{TM}}$ fibers, pyrolytic fiber coating (with $\mathrm{B}_{4} \mathrm{C}$ overlay) and $\mathrm{SiC}$-based oxidation inhibited matrix containing alternate layers of $\mathrm{SiC}$ and $\mathrm{B}_{4} \mathrm{C}$. The tests showed that the damage and failure of the composites at $1200{ }^{\circ} \mathrm{C}$ are caused by oxidation embrittlement in the two environments, air and steam. Fatigue from tension-compression cycles causes more extensive matrix cracking than tension-tension fatigue.
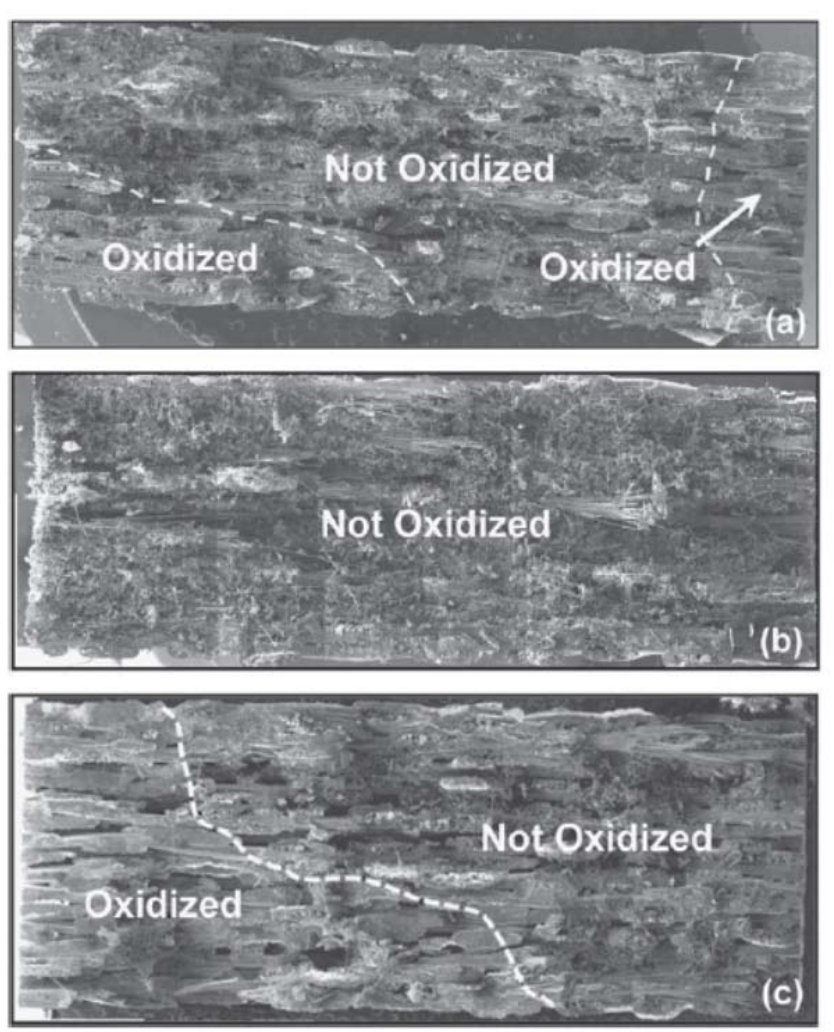

Figure 11: Fracture surface of specimens tested in tensioncompression mode at $1200 \mathrm{oC}$ conducted in (a) air at $160 \mathrm{MPa}$ after 23,277 cycles; (b) in air at $80 \mathrm{MPa}$ after $>200,000$ cycles, and (c) in steam at $160 \mathrm{MPa}$ after 2214 cycles. From reference ${ }^{44}$.

Because these cracks are exposed to the oxidizing environment, oxygen (or steam) enters through the cracks and reacts with $\mathrm{SiC}$ to form reaction products (silica) that fuse the fibers together. But once these fused fibers in the oxidized matrix fail, larger cracks form with appreciable depth. These unbridged 
matrix cracks cause the load redistribution to intact regions in the composites, and ultimately the composite fails. Damage is significantly accelerated in presence of steam, resulting in reduced fatigue performance. ${ }^{43,44}$ Figure 11 shows micrographs of the fracture surfaces in specimens tested in tensioncompression cycles in different environments. They show that a large fraction of fracture surface is oxidized, supporting the above mechanism. ${ }^{44}$

A micromechanics model of the thermomechanical behavior of minicomposites based on the matrix cracking mechanism in oxidizing environments was proposed by Pailler and Lamon. ${ }^{45}$ Matrix cracking is considered as a prerequisite for interphase oxidation. Matrix cracking involves multiple cracks that develop under load from microstructural heterogeneities in the matrix. As the cracks are arrested at the fiber/matrix interphase, debonding cracks are created. The latter allow oxygen ingress, which causes degradation of the fiber/matrix interphase at high temperatures. As the pyrocarbon interphase is consumed, the loads are progressively transferred to the fibers. Failure may occur as a result of fiber overloading. The model treats statistically the rate of interface degradation and crack healing induced by oxidation at high temperatures. Model predictions were found to be in good agreement with the room temperature behavior of $\mathrm{SiC} / \mathrm{SiC}$ minicomposites reinforced with $\mathrm{Hi}-\mathrm{Nicalon}$ fibers multifilament tows. 


\section{ADVANCED SiC/SiC COMPOSITES}

\subsection{ENGINEERED COMPOSITES WITH IMPROVED OXIDATION STABILITY}

After being established that degradation of mechanical properties in oxidizing atmospheres at high temperatures is caused by oxidation of the interphase (usually, pyrolytic carbon), efforts were recently directed at developing advanced composites with improved interphase oxidation resistance.

Multilayer interphases formed by repeated deposition sequences of $\mathrm{PyC}$ and $\mathrm{SiC}$ were reported to provide higher oxidation resistance and enhanced mechanical properties in comparison to those involving only one homogeneous PyC layer. ${ }^{46}$ For example, composites with four layers of $\mathrm{PyC} / \mathrm{SiC}$ coatings (Fig. 12) exhibit high strength and high toughness, and multiple crack deflection features that are interesting for high temperature applications. ${ }^{47}$ The composites were prepared by alternate sublayers of PyC and SiC deposited on Nicalon fibers by CVI. They were tested under tensile static loading (60$140 \mathrm{MPa})$ at high temperatures $\left(700-1200{ }^{\circ} \mathrm{C}\right)$ in air.

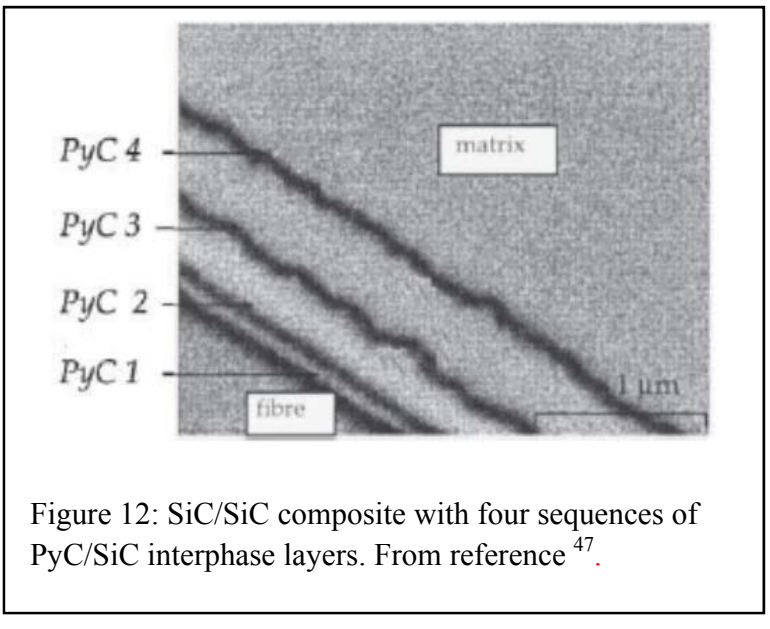
The use of the mulilayered interphase improved considerably the lifetime and the fatigue behavior, in comparison with the equivalent composite having a single PyC layer (50 $\mathrm{nm}$ thick). In addition, the multilayered composite showed interesting oxidation resistance below $1000{ }^{\circ} \mathrm{C}$ under stress lower than $120 \mathrm{MPa}$, even in presence of small and large densities of cracks. $^{47}$

Two generations of multilayered interphases, composed of carbon and silicon carbide, have been developed to act as a mechanical fuse in $\mathrm{SiC} / \mathrm{SiC}$ composites with improved oxidation resistance. From the mechanical point of view, pyrocarbon is the ideal interphase material, but it is sensitive to oxidation. On the other hand, $\mathrm{SiC}$ is oxidation resistant and acts as a protective layer for PyC. In the multilayered interphase the carbon mechanical fuse is split into thin sublayers, each being protected against oxidation by the neighboring SiC-based glass former layers. ${ }^{48}$ The first generation of multilayers was synthesized by isobaric CVI with sublayers of micrometer thickness, and used early generation SiC fibers (Nicalon NL202). The second generation of multilayer composites was developed with nanometer-size sublayers formed by pressure-pulsed CVI. They were reinforced with Hi-Nicalon SiC fibers. Minicomposites with a single two of fibers showed improved mechanical properties and oxidation resistance compared with their counterparts with a single layer of pyrocarbon coating. ${ }^{49}$ A great advantage of multilayer interphase coatings is the deflection of matrix cracks at the fiber surface, as shown in Fig. 13 for composites with multilayered interphases of the first and second generation. 


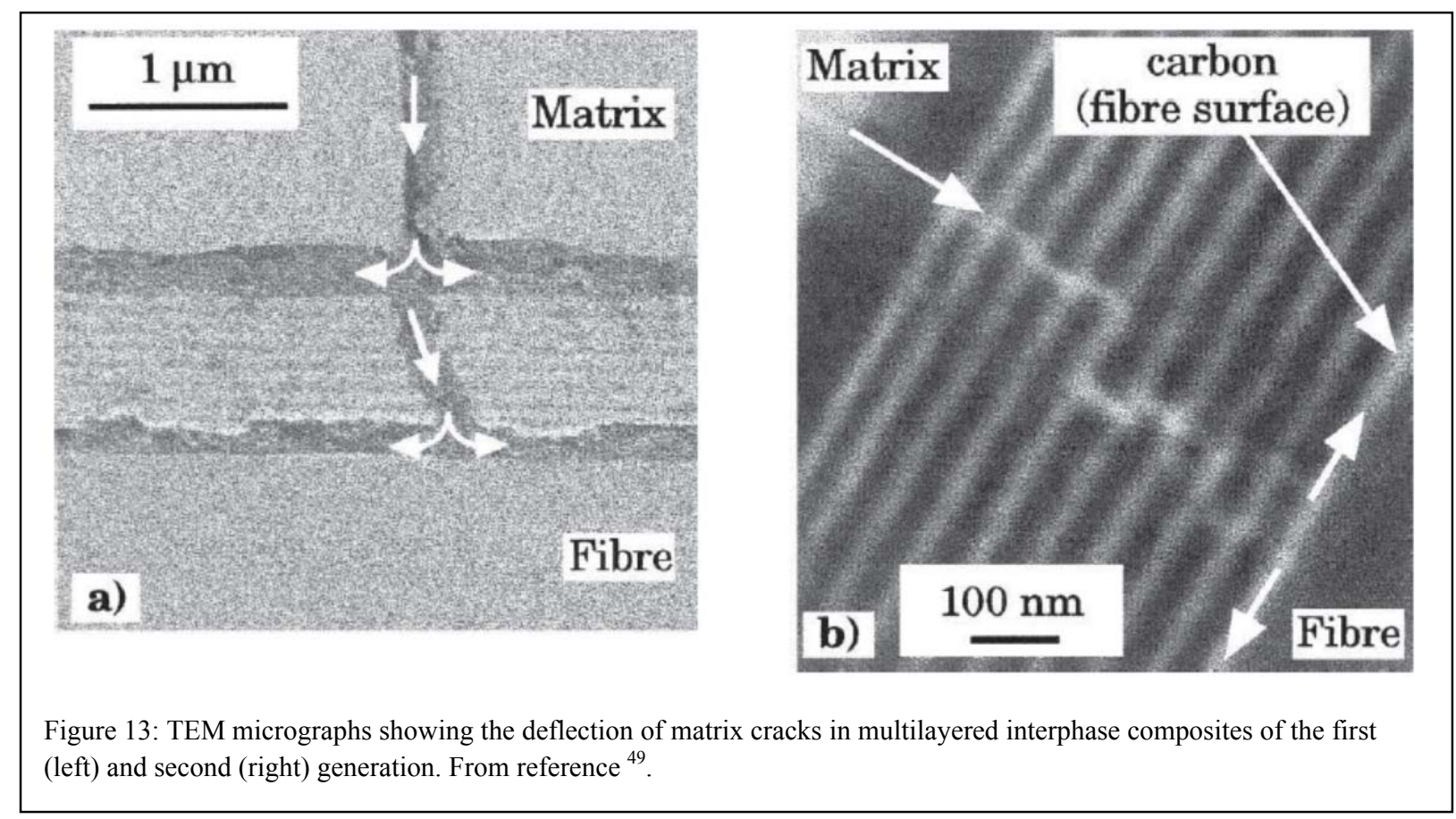

Another great advantage of multilayered interphase coatings is improvement of oxidation resistance. When sublayers have very low thickness, typically a few nanometers as obtained by the pressure-pulsed CVI, they display the self-healing behavior in oxidizing atmospheres. This is the effect of crack sealing oxides formed by reactions such as (2) and (3) in presence of oxygen and reactions (6) and (7) in presence of water, as shown above. The most common self-healing oxide phase examples are $\mathrm{SiO}_{2}, \mathrm{~B}_{2} \mathrm{O}_{2}$, and mixed compositions $\mathrm{B}_{2} \mathrm{O}_{3}-\mathrm{SiO}_{2}{ }^{50}$ Unfortunately, boron is incompatible with nuclear applications. However, the solution of boron-free hybrid interphases, such as $\mathrm{PyC}-\mathrm{SiC}$, and multilayer interphases, such as $(\mathrm{PyC}-\mathrm{SiC})_{\mathrm{n}}$ remains. For example, the lifetime in air at $700{ }^{\circ} \mathrm{C}$ under static loading of $1 \mathrm{D}$ SiC (HiNicalon)/SiC minicomposite is improved when the classical $\mathrm{PyC}_{100}$ single layer interphase is replaced by $\mathrm{a}\left(\mathrm{PyC}_{20}-\mathrm{SiC}_{50}\right)_{10}$ multilayer hybrid interphase (the subscripts stands for layer thickness in $\left.\mathrm{nm}\right){ }^{51}$

A different approach for improved oxidation stability of $\mathrm{SiC} / \mathrm{SiC}$ composites is using environmental barrier coatings $(\mathrm{EBC})$. It is known for example that $\mathrm{SiC}$-based systems are not suitable for long term use at high temperatures (above $1200{ }^{\circ} \mathrm{C}$ ) in high steam environments, such as that found in gas turbines. A research program conducted by NASA investigated other possible approaches for mitigation of accelerated oxidation caused by water vapor. Environmental barrier coatings for $\mathrm{SiC}$ developed under this program and the tests performed led to recognition of three efficient $\mathrm{EBC}$ formulations: calcium aluminosilicate, yttrium silicate, and barium-strontium aluminosilicate. ${ }^{52}$ These compositions may protect the $\mathrm{SiC}$ surface and reduce fiber recession in active oxidation conditions, but they might not be suitable for nuclear applications. A different method was proposed, which does not use other components but SiC. The double layer coating of $\mathrm{SiC}$ composite surface using the CVD-SiC process offered some protection in the $4000 \mathrm{~h}$ oxidation test of SiC-fiber boded composites (Tyrannohex ${ }^{\mathrm{TM}}$ ) at $1500{ }^{\circ} \mathrm{C}$ in air. However, some $\mathrm{SiO}_{2}$ scale spalling could not be avoided because of large volume changes occurring during $\alpha-\beta$ phase transformation in cyclic heating. ${ }^{36}$ More recently, it was reported that the mechanical properties and the oxidation resistance of $\mathrm{SiC} / \mathrm{CVI}-\mathrm{SiC}$ composites was improved (compared with 
$\mathrm{SiC} / \mathrm{SiC}$ composites with the PyC interphase) when the precursor infiltration and pyrolysis (PIP) method was used for coating $\mathrm{SiC}$ fibers with $\mathrm{SiC}$ interphase. ${ }^{53,54}$ In contrast with the PyC interphase, that is consumed on oxidation and allows silica to bond strongly with the fibers and matrix, the PIP-SiC interphase can effectively protect $\mathrm{SiC}$ fibers against thermal oxidation, based on tests conducted at $900{ }^{\circ} \mathrm{C}$ for 6 and $12 \mathrm{~h}$. However, PIP type composites cannot be used for nuclear applications.

\subsection{ENGINEERED COMPOSITES FOR USE IN NUCLEAR APPLICATIONS}

Because of their low induced radioactivity, excellent high temperature mechanical properties, and excellent radiation resistance, $\mathrm{SiC} / \mathrm{PyC} / \mathrm{SiC}$ composites fabricated from stoichiometric $\mathrm{SiC}$ fibers and pure $\mathrm{SiC}$ matrix are potential structural materials for gas-cooled high temperature nuclear reactors, of both fusion and fission type. ${ }^{55}$ This new and extremely demanding application raises specific constraints on the fibers, matrix, and interphase. The environment that $\mathrm{SiC} / \mathrm{SiC}$ composites would see in gas-cooled nuclear reactors is not radically different than that of their classical field of application, gas turbines. The conditions of temperature, gas pressure, and lifetime are about the same. However, the continuous exposure to strong oxidizing medium is not expected to occur in normal operation conditions of high temperature reactors. What is different is the continuous exposure to intense radiation by fast neutrons, $\alpha$ particles and electromagnetic radiation. Such severe radiation conditions are known to change the structure of materials, and hence their properties. ${ }^{51}$

Irradiation of monolithic $\mathrm{SiC}$ causes moderate swelling. Irradiation of $\mathrm{SiC}$ fibers causes different effects, depending on the composition and structure. Stoichiometric SiC fibers undergo moderate swelling like SiC phase. Fibers of the first and second generation (Nicalon and Hi-Nicalon) experience different degrees of swelling. The mismatch of volume changes under neutron irradiation is destructive to the composite. This is one important reason why third generation stoichiometric fibers are preferred for $\mathrm{SiC} / \mathrm{SiC}$ composites engineered for nuclear applications. Irradiation of $\mathrm{PyC}$ is known to induce anisotropic dimensional changes, which would induce residual thermal stress and might affect the fibermatrix bonding upon prolonged irradiation exposure. ${ }^{51}$ To avoid unwanted effects, the thickness of PyC interphase should be as low as possible, but large enough to allow matrix crack deflection. This can be achieved by using hybrid multilayered (PyC-SiC) ${ }_{n}$ interphase with thin (only a few nanometers) PyC sublayers. Indeed, the effect of neutron irradiation on composites with different type of interphase (either single layer $\mathrm{PyC}$ or multilayer $\mathrm{PyC}-\mathrm{SiC}$ ) showed better performance of multilayer composites with thin innermost PyC layers. ${ }^{56,57}$ As mentioned above, composites with multilayered interphases have the advantage of higher oxidation resistance overt those with one single PyC layer. ${ }^{47,49}$

The oxidation resistance of irradiated $\mathrm{SiC} / \mathrm{SiC}$ composites has not been reported yet, and is currently an active direction of research. Given that at high temperature, the microstructure of irradiated SiC quickly recovers toward its original unirradiated state, significant deviation in oxidation behavior is unlikely.

The low concentration of oxygen in the helium coolant of HTR may cause active oxidation and gasification of $\mathrm{SiC}$ at high temperatures, which might limit the use of $\mathrm{SiC} / \mathrm{SiC}$ composites in high temperature reactors. A recent study reported the behavior of $\mathrm{SiC} / \mathrm{SiC}$ composites at high temperatures in helium with low concentrations of oxygen. The $\beta$-SiC-SiC/PyC/SiC composite was made from HiNicalon fibers (second generation) with a $\mathrm{PyC}$ interphase and $\beta$-SiC matrix produced by CVI. A $\beta$-SiC coating was deposited by CVD on one face of the composite to act as an environmental barrier by closing the porosity on that face. Oxidation tests at $0.2 \mathrm{~Pa}$ and $2 \mathrm{~Pa} \mathrm{O}_{2}$ in helium were conducted up to $2000{ }^{\circ} \mathrm{C}$ by the gravimetric method. Water was introduced as the impurity in helium gas of different qualities ( $1 \mathrm{ppm}$ 
$\mathrm{H}_{2} \mathrm{O}$ and respectively 2 and $20 \mathrm{ppm}_{2}$ ). It was assumed that these conditions simulate the environment of gas-cooled fast reactors (GFR). ${ }^{58}$ Weight changes versus temperature at the two oxygen concentrations showed the existence of three domains in the zone of active oxidation (Fig. 14). For example, at low $\mathrm{O}_{2}$ partial pressure $(0.2 \mathrm{~Pa})$ the weight loss increases slowly with the temperature between 1400 and $1700{ }^{\circ} \mathrm{C}$; the weight loss continues with four time faster rate up to $1800{ }^{\circ} \mathrm{C}$, and then accelerates 3.6 more times between 1800 and $\sim 1925{ }^{\circ} \mathrm{C}$. At higher $\mathrm{O}_{2}$ partial pressure $(2 \mathrm{~Pa})$ the three-domain behavior is reproduced, but the transition temperatures are higher and the corresponding weight losses increase even further (Fig. 13). The differences reflect the damage introduced by oxidation of the $\beta$-SiC coating at 1270 and $1570{ }^{\circ} \mathrm{C}$. Even more damaging is sublimation of $\mathrm{SiC}_{(\mathrm{s})}$ into $\mathrm{Si}_{(\mathrm{g})}, \mathrm{Si}_{2} \mathrm{C}_{(\mathrm{g})}$, and $\mathrm{SiC}_{2(\mathrm{~g})}$ that starts above $1800{ }^{\circ} \mathrm{C}$ at $P_{\mathrm{O} 2}=0.2 \mathrm{~Pa}$ and $1890{ }^{\circ} \mathrm{C}$ at $P_{\mathrm{O} 2}=2 \mathrm{~Pa}$. Similar results were obtained on the face of the composite that was not coated by an environmental barrier of $\beta-\mathrm{SiC}$, and was concluded that coating was probably too thin and did not show a great influence on the oxidation behavior of $\beta-\mathrm{SiC}-\mathrm{SiC} / \mathrm{PyC} / \mathrm{SiC}$ in case of accident conditions leading to active oxidation. However, the coating remains essential for closing the porosity and preventing direct contact of oxidizing gas with the body of the composites at temperatures below about $1500-1900{ }^{\circ} \mathrm{C}$. The partial pressure of oxygen $(0.2-2 \mathrm{~Pa})$ did not have a strong

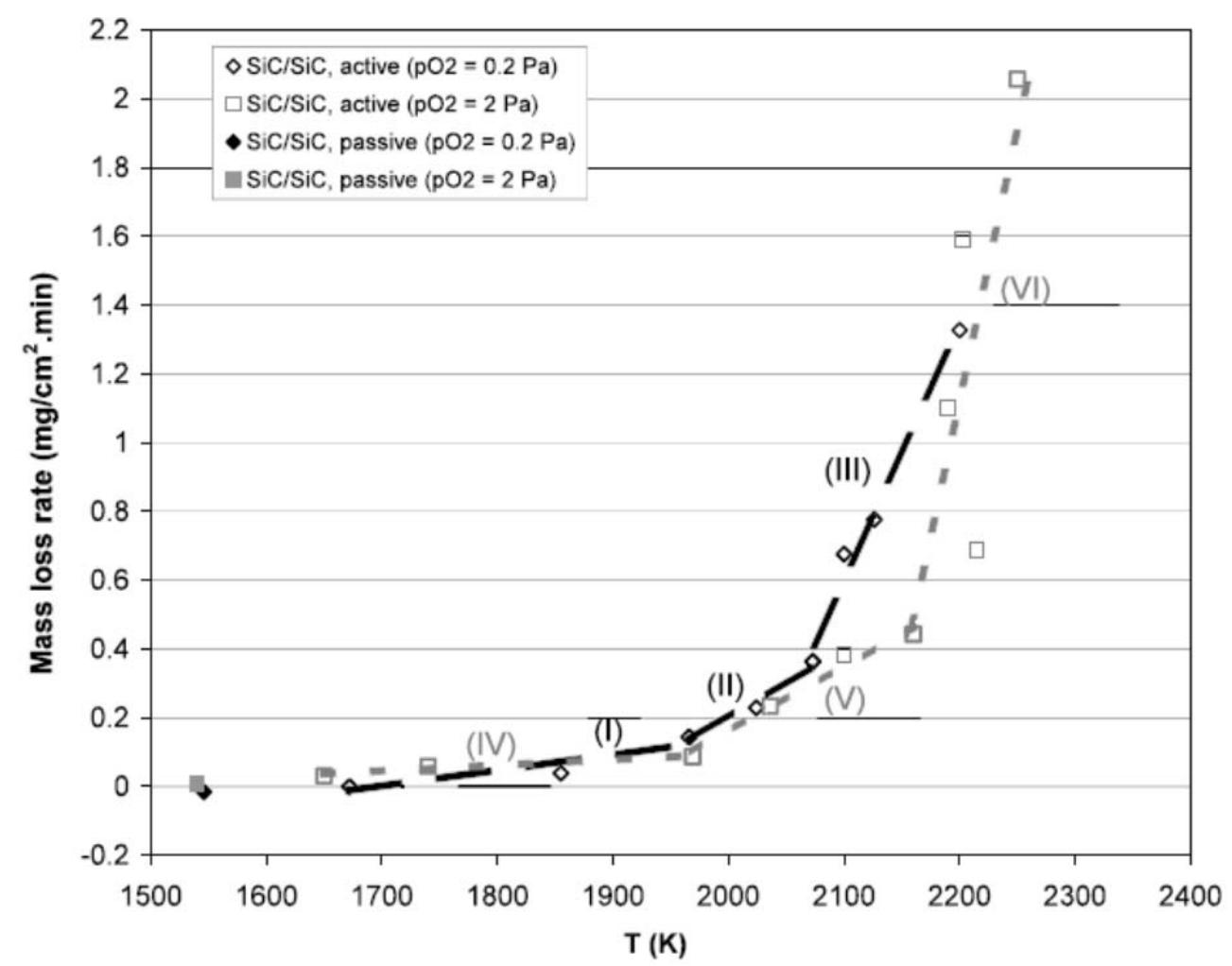

Figure 14: Mass loss rates of $\beta$-SiC-SiC/PyC/SiC composites oxidized in helium containing low concentrations of oxygen $(0.2$ and $2 \mathrm{~Pa}$ ). The three domains discussed in the text are labeled I, II and III for oxidation at $0.2 \mathrm{~Pa} \mathrm{O}_{2}$ and IV, V, VI for oxidation at $2 \mathrm{~Pa} \mathrm{O}_{2}$. Form reference ${ }^{58}$.

impact on the mass loss rate. ${ }^{58}$ Unfortunately, the fibers used were second generation Hi-Nicalon; no information is available about the behavior of third generation $\mathrm{SiC}$ fibers in similar conditions. 
The $\beta$-SiC coated $\mathrm{SiC} / \mathrm{PyC} / \mathrm{SiC}$ composite is a candidate for the cladding gas cooled fast reactor (GFR) and its chemical resistance in other environments that may develop in case of severe accident conditions was recently studied. ${ }^{59}$ Figure 15 compares active oxidation weight loss rates of $\beta$-SiC and $\beta$ $\mathrm{SiC}-\mathrm{SiC} / \mathrm{PyC} / \mathrm{SiC}$ composite in air, helium (with $2 \mathrm{~Pa} \mathrm{O}_{2}$ ) and in nitrogen (with $0.5 \mathrm{~Pa} \mathrm{O}_{2}$ ) at atmospheric pressure. The same three temperature domains were observed, which is not surprising. However, degradation of the composite was always faster than of monolithic $\beta$-SiC above $1700{ }^{\circ} \mathrm{C}$ because of the damage caused to $\beta$-SiC coating which enables oxidizing species to penetrate inside the composite. At very high temperature, oxidation and sublimation of SiC occurred deep inside the composites, while only a superficial layer of $\beta$-SiC was affected. This is caused by the presence of porosity that gives access to the pyrocarbon interphase inside the composite.

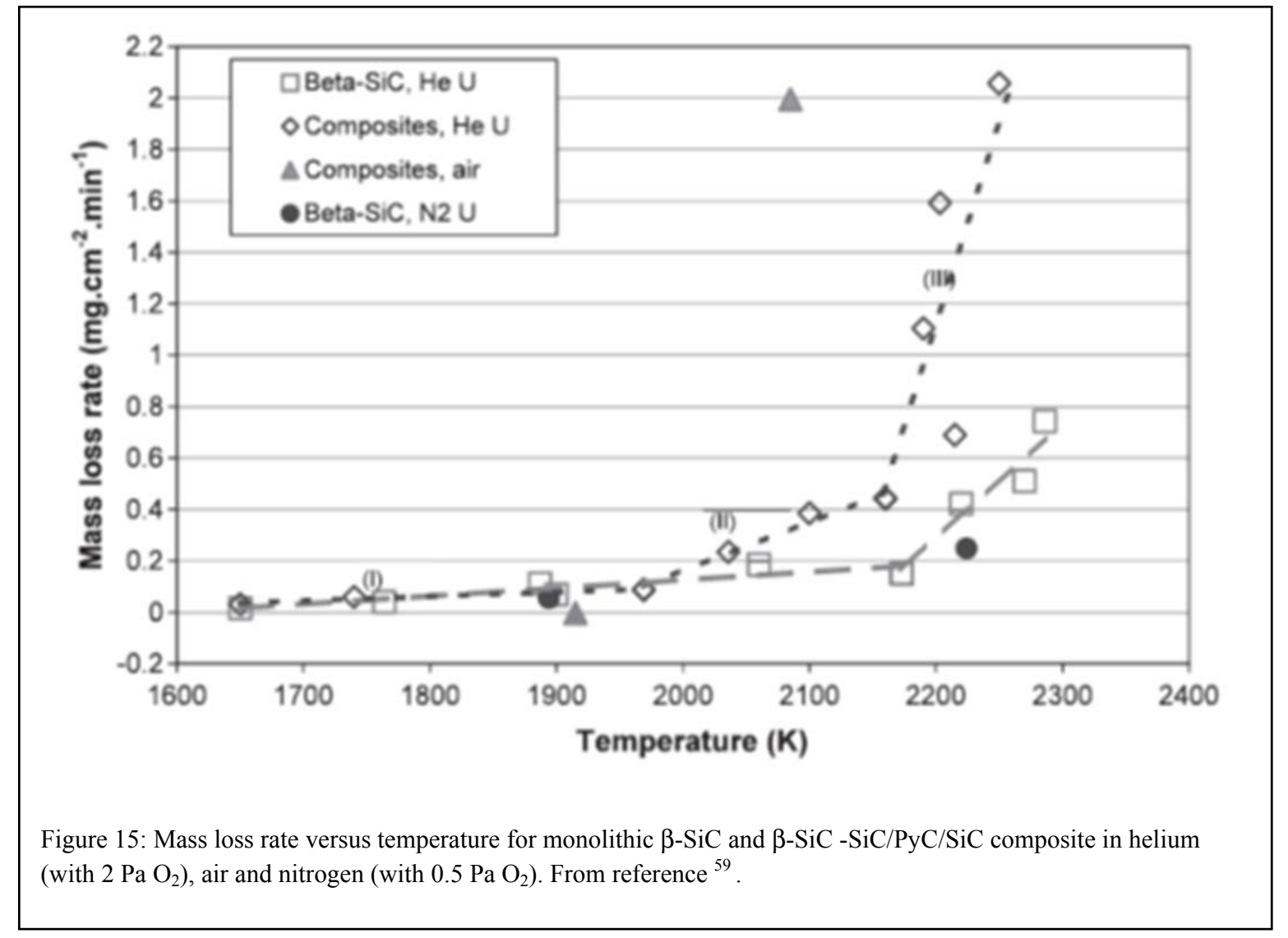

The conclusion of these studies ${ }^{3,24,58,59}$ is that in order to withstand high temperatures for prolonged durations that may occur in severe accident scenarios, the $\mathrm{SiC} / \mathrm{SiC}$ composites must be protected by thicker layers of $\beta$-SiC. Substitution of $\mathrm{He}$ (with $2 \mathrm{~Pa} \mathrm{O}_{2}$ ) by $\mathrm{N}_{2}$ (with $0.5 \mathrm{~Pa} \mathrm{O}_{2}$ ) did not cause important differences in oxidation behavior of $\beta$-SiC (Fig. 14). When a sudden temperature increase was applied to $\beta$-SiC samples preoxidized in passive conditions, transition from passive to active oxidation occurred and surface damage was identified on the $\beta$-SiC monolith. The nature of the gas atmosphere had an effect on the final temperature achieved in these experiments. Helium, with better thermal conductivity than nitrogen, allowed a lower final temperature $\left(1725^{\circ} \mathrm{C}\right)$ than nitrogen $\left(2000{ }^{\circ} \mathrm{C}\right)$, but since nitrogen did not 
reduce the damage of $\beta-\mathrm{SiC}$, the authors did not recommend replacing helium by nitrogen in the case of a sudden accidental loss of coolant. ${ }^{59}$

The behavior of $\mathrm{SiC} / \mathrm{SiC}$ composites in helium gas with higher oxygen content was studied experimentally to evaluate the suitability of $\mathrm{SiC} / \mathrm{SiC}$ composites as candidate structural materials for fusion reactor blanket helium gas-cooled solid breeder blanket (HCSB) reactors. One recent study ${ }^{60}$ addressed the difference in oxidation behavior between conventional composites with pyrolytic carbon interphase (PyC-SiC/SiC) and advanced multilayer interphase (ML-SiC/SiC) in $\mathrm{He}$ with $150 \mathrm{~Pa} \mathrm{O}_{2}$ at $1000-1200{ }^{\circ} \mathrm{C}$. The advanced $\quad \mathrm{ML}-\mathrm{SiC} / \mathrm{SiC}$ composite showed small weight change at both 1000 and $1200{ }^{\circ} \mathrm{C}$, while the conventional PyC-SiC/SiC composite behaved similarly only at $1200{ }^{\circ} \mathrm{C}$. The good stability was due to $\mathrm{SiO}_{2}$ which formed with relatively high rate and was able to seal the specimen surface and to protect the PyC interphase (passive oxidation). In contrast, the conventional $\mathrm{PyC}-\mathrm{SiC} / \mathrm{SiC}$ composite showed significant weight loss at $1000{ }^{\circ} \mathrm{C}$, where surface sealing was not efficient and significant degradation of the pyrolytic carbon layer occurred (Fig. 16).

At high $\mathrm{O}_{2}$ partial pressures $(10-150 \mathrm{~Pa})$ the weight loss caused by oxidation of $\mathrm{SiC} / \mathrm{SiC}$ composites at $1100{ }^{\circ} \mathrm{C}$ depends on the oxygen
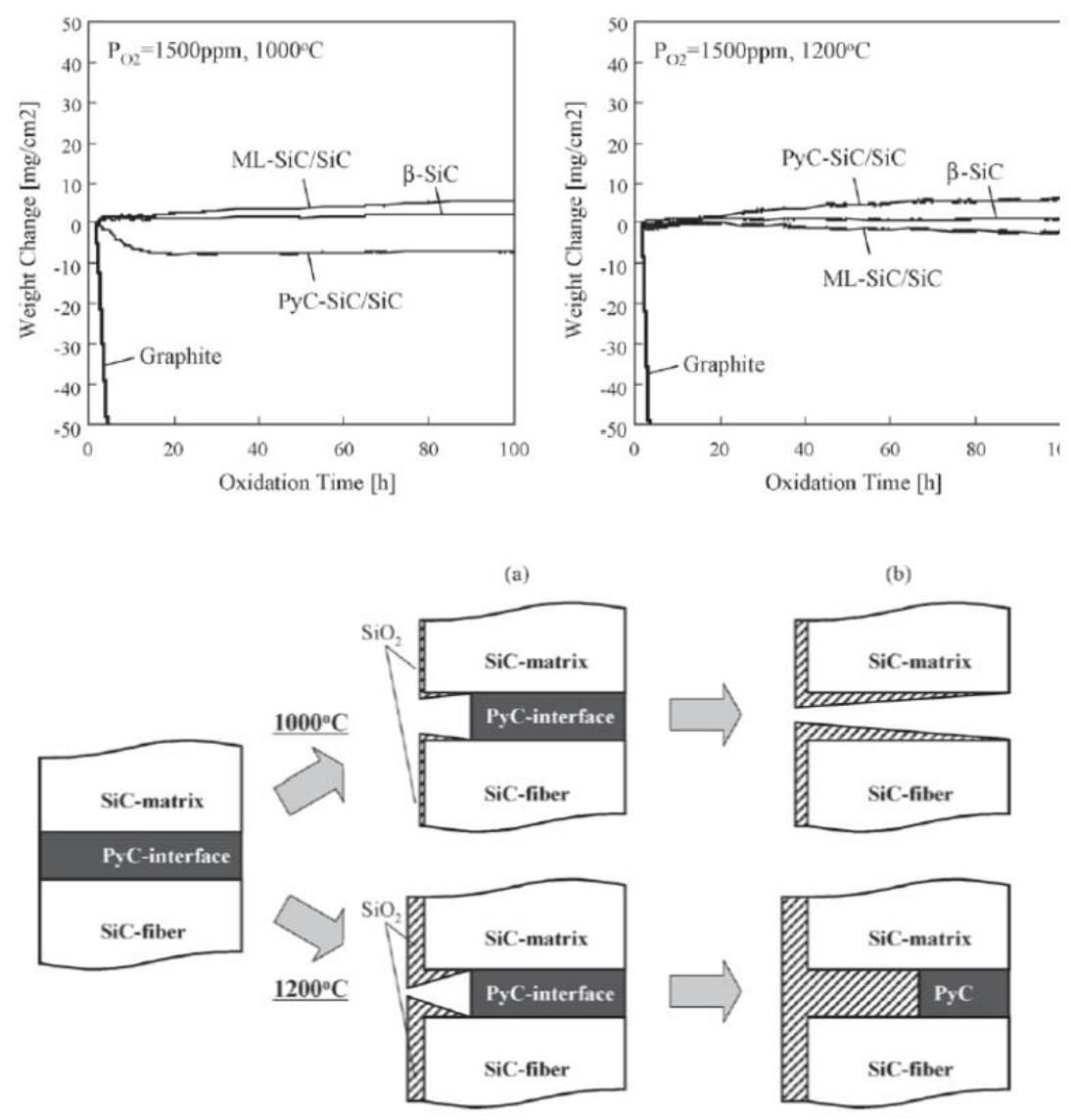

(c)

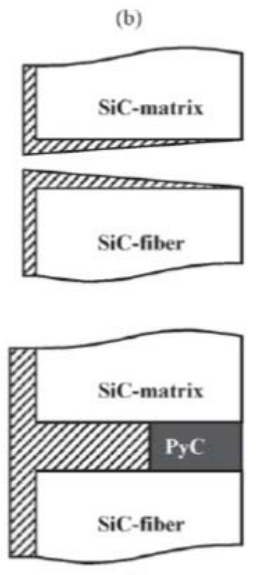

(d)

Figure 16: Top: Weight change during exposure to helium containing $150 \mathrm{~Pa} \mathrm{O}_{2}$ of conventional PyC-SiC/SiC composite and pf multilayer ML-SiC/SiC composite. The behavior of monolithic $\beta-\mathrm{SiC}$ and graphite is shown for comparison. Bottom: Schematic diagram of the oxidation mechanism of $\mathrm{PyC}-\mathrm{SiC} / \mathrm{SiC}$ composite. From reference ${ }^{60}$. pressure. The kinetics is governed by the linear-parabolic law, with the rate constants of the linear region being correlated with the $\mathrm{O}_{2}$ partial pressure. ${ }^{61}$ This behavior contrasts with the report cited above ${ }^{58}$ according to which oxidation is not sensitive to $P_{\mathrm{O} 2}$ in the range of $0.2-2 \mathrm{~Pa}$. The difference of behavior may possibly be caused by the quality of $\mathrm{SiC}$ fibers used (Nicalon first generation in one report ${ }^{61}$ versus Hi-Nicalon in another ${ }^{58}$ ). Gasification rates of the same Nicalon-based composite in helium containing $1 \%$ and $0.1 \%$ hydrogen were 6 to 26 times slower than the rates in oxygen, based on the linear kinetics approximation. ${ }^{61}$ 


\section{CHEMICAL COMPATIBILITY OF SIC/SIC COMPOSITES IN THE ENVIRONMENT OF ADVANCED NUCLEAR REACTORS}

Ceramic matrix composites are being evaluated for use at high temperatures and high radiation fields in advanced reactor concepts, including high temperature gas-cooled reactor (HTGR), very high temperature reactor (VHTR), gas fast reactor (GFR), sodium fast reactor (SFR), and fluoride-cooled hightemperature reactor (FHR). $\mathrm{SiC} / \mathrm{SiC}$ ceramic matrix composites have excellent thermal properties, mechanical strength, and radiation resistance, all desirable properties for nuclear applications. However, their qualification as component materials in each of the above reactor concepts depends critically on the stability of $\mathrm{SiC} / \mathrm{SiC}$ composites in contact with the chemical environment of the coolant system.

The operating temperature in VHTR reactors may reach $1000{ }^{\circ} \mathrm{C}$ over sustained periods of time, and the gas atmosphere is expected to be helium with small content of impurities $\left(\mathrm{CO}, \mathrm{CO}_{2}, \mathrm{CH}_{4}, \mathrm{H}_{2}, \mathrm{H}_{2} \mathrm{O}\right.$, $\mathrm{O}_{2}$ ) at pressures that may reach 75 bar. The slightly oxidizing environment and the presence of water vapor may be quite aggressive to $\mathrm{SiC} / \mathrm{SiC}$ composites. Additional factor operating under high gas flow rates is the mechanical corrosion caused potentially by particles transported by the gas. ${ }^{62}$ Although comprehensive studies of the environmental effects on $\mathrm{SiC} / \mathrm{SiC}$ composites under these special conditions are missing, the current technical progress and the continuous improvement of materials properties allows for drawing several educated conclusions on the compatibility issues.

The latest generation of $\mathrm{SiC} / \mathrm{SiC}$ composites for nuclear applications is based on stoichiometric $\mathrm{SiC}$ fibers, thin pyrolytic carbon interphase or multilayered interphase with alternating layers of $\mathrm{SiC}$ and pyrolytic carbon, and a crystalline high purity $\beta$-SiC matrix obtained by chemical vapor infiltration (CVI). An environmentally barrier coating may also be required to seal the surface porosity. This design is the result of continuous properties improvement over three generations of SiC fibers and two generations of interphase compositions. Historically, composites with improved mechanical properties, such as fatigue resistance under cyclic operation, were needed for high temperature operation in the oxidizing environment encountered in gas turbines. Now it is known that the combination of high-purity stoichiometric $\mathrm{SiC}$ fibers with thin interphase layers or multilayers and crystalline $\beta$-SiC matrix imparts superior chemical resistance against oxidation by air and steam with high oxidation potential. However, very little is known about the behavior of these same composites in the helium coolant with low oxidation potential encountered in gas-cooled nuclear reactors.

A few studies were recently published on the effect of different accident condition scenarios on the environmental resistance of $\mathrm{SiC} / \mathrm{SiC}$ composites at low oxygen concentrations in helium. ${ }^{24,58}$ Unfortunately the $\mathrm{SiC}$ fibers used were Hi-Nicalon of the second generation; no information was found about the behavior in similar conditions of composites obtained from third generation, stoichiometric $\mathrm{SiC}$ fibers. Even so, the few existing data demonstrate good oxidation stability at low oxygen concentrations in the temperature range of normal operation conditions of VHTR. For example, Fig. 13 (above) shows that $\beta$-SiC/PyC/SiC composites experience passive oxidation up to $1300{ }^{\circ} \mathrm{C}$ at 0.2 and $2 \mathrm{~Pa} \mathrm{O}_{2}{ }^{58}$ In these composites, the fiber was second generation Hi-Nicalon. The third generation Hi-Nicalon $\mathrm{S}$ fibers have even better oxidation resistance, with active to passive transition at lower oxygen pressure, as shown in Fig, 5 (above). ${ }^{25}$ According to that figure, SiC fibers (Nicalon-S) would suffer passive oxidation limits in the range of temperatures (below $1300 \mathrm{~K}$ or about $1000{ }^{\circ} \mathrm{C}$ ) and oxygen partial pressures $(<1 \mathrm{~Pa})$ that may be encountered in normal operation conditions. This is an encouraging result, but it should be noted that the transition ranges reported in Fig. 5 (above) are based on calculations and are not compared 
against direct experimental data. Moreover, little or nothing is available about the oxidation resistance and microstructural changes suffered by $\mathrm{SiC} / \mathrm{SiC}$ composites in the same conditions.

Most of information available was obtained from mechanical testing of composites exposed at high temperatures in conditions where gasification by decomposition, volatilization, or active oxidation is of concern (vacuum or inert gas with low concentrations of oxidant gas). For example, it has been reported that composites fabricated with Hi-Nicalon S fibers maintain high strength in vacuum up to $1700{ }^{\circ} \mathrm{C}$ and do not show structure deterioration up to $1900{ }^{\circ} \mathrm{C}$ in vacuum. ${ }^{29}$ Consistent with that, composites fabricated with Tyranno SA fibers were reported to maintain stable mechanical properties in air up to $1300{ }^{\circ} \mathrm{C}$, due to the engineered interphase composed of $\mathrm{SiC}$ and $\mathrm{PyC}$ sublayers and the high crystallinity of the $\beta$-SiC matrix. ${ }^{37}$ According to indirect information, SA-Tyrannohex composites fabricated with Tyranno-SA fibers and protected by a secondary CVD SiC surface layer maintained their mechanical strength after $4000 \mathrm{~h}$ exposure in air at $1500{ }^{\circ} \mathrm{C} .{ }^{36}$ At these conditions, carbon based materials and metal alloys fail.

Although experimental data about the behavior of nuclear grade $\mathrm{SiC} / \mathrm{SiC}$ composites in conditions relevant to either normal operation or off-normal conditions in VHTR are scarce, all results available so far point to the conclusion that $\mathrm{SiC}$ composites engineered for nuclear applications have a great environmental resistance and maintain mechanical properties up to $1500-1700{ }^{\circ} \mathrm{C}$ in vacuum and $1300-$ $1500{ }^{\circ} \mathrm{C}$ in air. These temperatures are way above the range of normal operation regime $\left(750-900{ }^{\circ} \mathrm{C}\right)$. Extrapolated behavior of stoichiometric fibers of the third generation shows that they should be stable against passive oxidation at low oxygen concentration at the temperatures of normal operation conditions.

The control of coolant chemistry is needed to protect the core components. A pure helium coolant should not be of concern, but in reality the coolant may have a slight oxidizing character either because traces of $\mathrm{O}_{2}, \mathrm{CO}_{2}$, or $\mathrm{H}_{2} \mathrm{O}$ are expected to be always present, and also because slightly oxidizing potential is required to protect metallic parts against carburization and embrittlement. At low oxygen concentrations, as expected for the He coolant, $\mathrm{SiC}$ may experience gasification by active oxidation and volatilization at high temperatures. These reactions would totally damage the composites. It appears however that sublimation of Hi-Nicalon fibers occurs at higher temperatures $\left(1800{ }^{\circ} \mathrm{C}\right)$ than those that might hypothetically develop in severe accident conditions. On the other hand, high oxygen supply is to be avoided because oxidation of the pyrolytic carbon interphase occurs even at intermediate temperatures. Other chemical factors than must be controlled in the coolant are water and methane concentrations, because they interfere with silica growth. ${ }^{13}$

The available sources contain very little information about the long term behavior of $\mathrm{SiC} / \mathrm{SiC}$ composites in conditions simulating normal operation conditions of gas-cooled reactors. Recently published data $^{58,59}$ are targeted to GFR-relevant environments rather than VHTR. Long-term oxidation behavior studies in impure helium, both in irradiation-free and irradiation active conditions, are still needed. Although $\mathrm{SiC} / \mathrm{SiC}$ composites have been considered for fusion reactor gas-cooled blanket, there still is a huge knowledge gap between the needs to select and qualify these composites in gas-cooled high-temperature fission reactors and the available information on the behavior of composites in other high-temperature impure helium conditions, such as the gas turbine environment.

Last, it is noted that most of the experimental results available today have been measured in short time experiments, a few hours at most. One notable exception is the $4000 \mathrm{~h}$ long experiment at low oxygen pressures reported above. ${ }^{58}$ More long-term experiments are needed with advanced $\mathrm{SiC} / \mathrm{SiC}$ composites, using generation III fibers, engineered interphases, protecting coatings etc. These studies are needed to obtain quantitative results and validate the lifetime projections based on the limited corpus of 
data existing today. The methodology might be oriented towards determination of long time oxidation behavior of each constituent in the composite (advanced fibers, engineered interphase, matrix) and then of nuclear grade composites themselves. Investigation of the oxidation mechanisms in extreme environment conditions should enable development of predictive models and standardization of qualification procedures. $^{13}$ 


\section{CONCLUSIONS}

The information available in the literature on chemical reactivity of $\mathrm{SiC} / \mathrm{SiC}$ composites in contact with the helium coolant of gas-cooled reactors was reviewed in this literature report. Special emphasis was placed on collecting available information regarding chemical reactivity of different components (SiC fibers and monoliths, and fiber/matrix interphase) of $\mathrm{SiC} / \mathrm{SiC}$ composites in contact with various environments, containing oxygen, water vapor and other components, and on the effect of high temperature exposure to these chemically aggressive conditions. The recent progress in development of nuclear grade $\mathrm{SiC}$ fibers and composites led to an increased chemical stability of $\mathrm{SiC}$ fibers and composites from the third generation (nuclear grade) of materials. The most advanced composites with engineered structures and added environmental barrier protection have chemical resistance that would allow them maintain mechanical properties at the highest temperatures (1200-1300 or higher $\left.{ }^{\circ} \mathrm{C}\right)$ that might be projected in the extreme conditions of an air- or water ingress scenario. At these extreme conditions carbon-based materials and metal alloys fail. However, further research is required to assess the long-term stability of these advanced $\mathrm{SiC} / \mathrm{SiC}$ composites in contact with traces of water or oxygen

that might be present in the helium coolant during normal operation. Given that the microstructure of irradiated $\mathrm{SiC}$ recovers quickly at high temperatures to the original, non-irradiated form, significant deviations of oxidation behavior caused by irradiation with fast neutrons are unlikely. 


\section{REFERENCES}

${ }^{1}$ J P Bonal, A Kohyama, J can der Laan, L Snead, Graphite, ceramics, and ceramic composites for high temperature nuclear power, MRS Bulletin 34 (2009) 28-34

${ }^{2}$ Y Katoh, L L Snead, T D Burchell, W E Windes, Composite technology development plan, ORNL/TM2009/185 (January 2010)

${ }^{3}$ L Charpentier, M Balat-Pichelin, F Audubert, High temperature oxidation of SiC under helium with low-pressure oxygen: Part I: Sintered $\alpha$-SiC, J European Ceram Soc 30 (2010) 2653-2660

${ }^{4}$ MP Kissane, A review of radionuclide behavior in the primary system of a very-high-temperature reactor, Nucl. Eng. Des. 239 (2009) 3076-3091

${ }^{5}$ R D Burnette, N L Baldwin, Primary coolant chemistry of the Peach Bottom and Fort St. Vrain high temperature gas-cooled reactors, in Specialists Meeting on Coolant Chemistry, Plate-Out Decontamination in Gas-Cooled Reactorts, Juelich, Germany, 2-4 Dec, IAEA IWGGCR-2

${ }^{6} \mathrm{X} \mathrm{Yu}, \mathrm{S} \mathrm{Yu}$, Analysis of fuel element matrix graphite corrosion in HTR-PM for normal operating conditions, Nucl Eng Des 240 (2010) 738-743

${ }^{7}$ M S Yao, RP Yang, ZY Liu, XD He, J Li, The helium purification system of the HTR-10, Nucl Eng Des 218 (2002) 163-167

${ }^{8}$ S Fujikawa, H Hayashi, T Nakazawa, K Kawasaki, T Iyoku, S Nakagawa, N Sabaka, Achievement of rreactor-outlet coolant temperature of $950{ }^{\circ} \mathrm{C}$ in HTTR. J Nucl Sci Technol. 41 (2004) 1245-1254

${ }^{9}$ E S Kim, H C No, B J Kim, C H Oh, Estimation of graphite density and mechanical strength variation of VHTR during air-ingress accident, Nucl Eng Des 238 (2008) 837-847

${ }^{10}$ R Moormann, Phenomenology of graphite burning in massive air ingress accidents, Proc. HTR2006, $3{ }^{\text {rd }}$ International Topical Meeting on High Temperature Reactor Technology, October 12-4, 2006, Johannesburg, South Africa

${ }^{11}$ B E Deal, A S Grove, General relationship for the thermal oxidation of silicon, J Appl. Phys 36 (1965) 3770-3778

12 J D Cawley, Oxygen diffusion in silica and corrosion of ceramics, in K G Nickel (ed.), "Corrosion of Advanced Ceramics - Measurements and Modeling", The Netherlands (1993), pp. 35-46.

${ }^{13} \mathrm{C}$ Cabet, Review: Oxidation of $\mathrm{SiC} / \mathrm{SiC}$ composites in low oxidizing and high temperature environment, in "Materials Issues for Generation IV Systems", V. Ghetta et al. (eds), Springer Science + Business Media B.V. (2008) pp. 351-366.

${ }^{14} \mathrm{~J}$ E Antill, J B Wartburton, Active to passive transition in the oxidation of SiC, Corrosion Sci 11 (1971) 337-342. 
${ }^{15}$ W L Vaughn, H G Maahs, Active-to-passive transition in the oxidation of silicon carbide and silicon nitride in air, J Am Ceram Soc 73 (1990) 1540-1543

${ }^{16} \mathrm{~J}$ W Hinzem H C Graham, The active oxidation of $\mathrm{Si}$ and $\mathrm{SiC}$ in the viscous gas-flow regime, $J$ Electrochem Soc 123 (1976) 1066-1073

${ }^{17} \mathrm{E} \mathrm{J}$ Opila N S Jacobson, $\mathrm{SiO}_{(\mathrm{g})}$ formation from $\mathrm{SiC}$ in mixed oxidizing and reducing gases, Oxidation of Metals 44 (1995) 527-544

${ }^{18} \mathrm{R}$ E Tessler, Theory and experiment in corrosion of advanced ceramics, in K G Nickel (ed) "Corrosion of Advanced Ceramics - Measurements and Modeling", The Netherlands (1993), pp. 3-22

${ }^{19}$ T Nakashima, T Goto, Y Iguchi, T Hirai, High-temperature oxidation of chemically vapor-deposited silicon carbide in wet oxygen at 1823 to 1923 K, J Am Ceram Soc 73 (1990) 3580-3584

${ }^{20} \mathrm{~N}$ S Jacobson, A J Eckel, A K Misra, D L Humphrey, reactions of $\mathrm{SiC}$ with $\mathrm{H}_{2} / \mathrm{H}_{2} \mathrm{O} / \mathrm{Ar}$ mixtures at $1300{ }^{\circ} \mathrm{C}, \mathrm{J}$ Am Ceram Soc 73 (1990) 2330-2332

${ }^{21}$ T Narushima, T Goto, Y Yokoyama, Y Iguchi, T Hirai, High-temperature oxidation of chemically vapor-deposited silicon carbide in CO-CO $\mathrm{CO}_{2}$ atmosphere, J Am Ceram Soc 76 (1993) 2521-2524

${ }^{22}$ M Balat, R Berjoan, G Pichelin, D Rochman, High-temperature oxidation of sintered silicon carbide under pure $\mathrm{CO}_{2}$ at low pressures: active-passive transition. Appl. Surf Sci 133 (1998) 115-123

${ }^{23}$ L Filipuzzi, R Naslain, C Jaussaud, Oxidation kinetics of $\mathrm{SiC}$ deposited from $\mathrm{CH}_{3} \mathrm{SiCl}_{3} / \mathrm{H}_{2}$ under CVI conditions, J Mater Sci 27 (1992) 3330-3334.

${ }^{24}$ L Charpentier, M Balat-Pichelin, H Glenat, E Beche, E Laborde, F Audubert, High-temperature oxidation of $\mathrm{SiC}$ under helium with low-pressure oxygen. Part 2: CVD $\beta$-SiC, J European Ceram Soc 30 (2010) 2661-2670.

${ }^{25}$ T Shimoo, Y Morisada, K Okamura, Oxidation behavior of Si-M-C-O fibers (Nicalon) under oxygen partial pressures from $10^{2}$ to $10^{5}$ Paat 1773 K, J am Ceram Soc 83 (2000) 3049-3056

${ }^{26}$ T Shimoo, F Toyoda, K Okamura, Oxidation kinetics of low-oxygen silicon carbide fiber, J Mater Sci, 35 (2000) 3301-3306.

${ }^{27} \mathrm{~T}$ Shimoo, K Okamura, Y Morisada, Active to passive oxidation transition for polycarbosilane-derived silicon carbide fibers heated in $\mathrm{Ar}_{-} \mathrm{O}_{2}$ gas mixtures, J Mater Sci 37 (2002) 1793-1800

${ }^{28}$ R Naslain, A Guette, F Rebillat, S Le Gallet, F Lamouroux, L Filipuzzi, C Louchet, Oxidation mechanisms and kinetics of SiC-matrix composites and their constituents, J Mater Sci 39 (2004) 7303.

${ }^{29}$ H Araki, H Suzuki, W Yang, S Sato, T Noda, Effect of high temperature heat treatment in vacuum on microstructure and bending properties of $\mathrm{SiC}_{\mathrm{f}} / \mathrm{SiC}$ composites prepared by $\mathrm{CVI}, \mathrm{J}$ Nucl Mater 258-263 (1998) 1540-1545,

${ }^{30} \mathrm{C}$ Labrugere, A Gette, R Naslain, Effect of ageing treatments at high temperatures on the microstructure and mechanical behavior of $2 \mathrm{D}$ Nacalon/C/SiC composites. I Ageing under vacuum or argon, J. Eur. Ceram Soc. 17 (1997) 623-640. 
${ }^{31}$ H Araki, W Yang, H Suzuki, Q Hu, C Busabok, T Noda, Fabrication and flexural properties of Tyranno-SA/SiC composites with carbon interlayer by CVI, J Nucl. Mater. 329-333 (2004) 567-571

${ }^{32}$ L Filipuzzi, G Camus, R Naslain, J Thebault, Oxidation mechanism and kinetics of 1D-SiC/C/SiC composite materials: An experimental approach, J Am. Ceram Soc 77 (1994) 459-466

${ }^{33} \mathrm{Z}$ Zhu, Fatigue behavior of ceramic matrix composites oxidized at intermediate temperatures, Materials Trans 47 (2006) 1965-1967.

${ }^{34}$ M Huger, D Fargeot, C Gault, Ultrasonic characterization of oxidation mechanism in Nicalon/C/SiC composites, J Am Ceram Soc 77 (1994) 2554-2560

${ }^{35}$ S Ochiai, S Kimura, H Tanaka, M Tanaka, M Hojo, K Morishita, H Okuda, H Nakayama, M Tamura, $\mathrm{K}$ Shibata, M Sato, Degradation of $\mathrm{SiC} / \mathrm{SiC}$ composite due to exposure at high temperatures in vacuum in comparison with that in air, Composites A 35 (2004) 33-40

${ }^{36}$ A Otsuka, Y Matsumura, K Hosono, R Tanaka, Long term oxidation of a SiC-bonded composite in air at $1500{ }^{\circ} \mathrm{C}, \mathrm{J}$ Eur. Ceram Soc. 23 (2003) 3125-3134

${ }^{37}$ T Nozawa, K Ozawa, Y Katoh, A Kohyama, Effect of heat treatment on microstructure and mechanical properties of stoichiometric SiC/SiC composites, Mater Trans 45 (2004) 307-310.

${ }^{38}$ K L More, P F Tortorelli, M K Ferber, J R Keiser, Observation of accelerated silicon carbide recession by oxidation at high water pressures, J Am. Ceram Soc, 83 (2000) 211-213.

${ }^{39}$ H Kleykamp, V Schauer, A Skokan, Oxidation behavior of SiC fibre reinforced SiC, J Nucl Mater 227 (1995) 130-137

${ }^{40}$ L Cheng, Y Xu, L Zhang, X Yin, Oxidation behavior of three-dimensional SiC/SiC composites in air and combustion environment, Composites A 31 (2000) 1015-1020.

${ }^{41}$ X Luan, L Cheng, Y Xu, L Zhang, Stressed oxidation behavior of SiC matrix composites in combustion environments, Materials Letters, 61 (2007) 4114-4116.

${ }^{42}$ P Reynaud, D Rouby, G Fantozzi, Effects of temperature and oxidation on the interfacial shear stress between fibres and matrix in ceramic-matrix composites, Acta Mater. 46 (1998) 2461-2469

${ }^{43}$ M B Ruggles-Wrenn, D T Christensen, A L Chamberlain, J E Lane, T S Cook, Effect of frequency and environment on fatigue behavior of a CVI SiC/SiC ceramic matrix composite at $1200{ }^{\circ} \mathrm{C}$, Composites Sci Technol 71 (2011) 190-196

${ }^{44}$ M B Ruggles-Wrenn, T P Jones, Tension-compression fatigue of a SiC/SiC ceramic matrix composite at $1200{ }^{\circ} \mathrm{C}$ in air and steam, Int. J Fatigue 47 (2013)154-160

${ }^{45}$ F Pailler, J Lamon, Micromechanics based model of fatigue/oxidation for ceramic matric composites, Composites Sci Technol 65 (2005) 369-374

${ }^{46}$ C Droilard, J Lamon, X Bourrat, Strong interface in CMCs, a condition for efficient multilayer interphases, Mat Res Soc Proc 365 (1995) 371-376. 
${ }^{47} \mathrm{~S}$ Pasquier, J Lamon, R Naslain, Tensile static fatigue of 2D SiC/SiC composites with multilayered $(\mathrm{PyC}-\mathrm{SiC})_{\mathrm{n}}$ interphases at high temperatures in oxidizing atmosphere, Composites A 29 (1998) 11571164.

${ }^{48} \mathrm{~S}$ Bertrand, C Droillard, R Pailler, X Bourrat, R Naslain, TEM structure of $(\mathrm{PyC} / \mathrm{SiC})_{\mathrm{n}}$ multilayered interphases in $\mathrm{SiC} / \mathrm{SiC}$ composites, J European Ceram Soc 20 (2000) 1-13

${ }^{49} \mathrm{~S}$ Bertrand, R Pailler, J Lamon, $\mathrm{SiC} / \mathrm{SiC}$ minicomposites with nanoscale multilayered fiber coating, Composites Sci Tech 61 (2001) 3630357,

${ }^{50} \mathrm{R}$ Naslain, Hybrid ceramic matrix fibrous composites: An overview, IOP Conf. Series: Materials Science and Engineering 18 (2011) 082002

${ }^{51}$ RR Naslain, R J F Pailler, J L Lamon, Single and multilayered interphases in SiC/SiC composites exposed to severe environmental conditions: An overview. Int. J Appl. Ceram Technol 7 (2010) 26375

${ }^{52}$ H E Eaton, G D Linsey, Accelerated oxidation of SiC CMC's by water vapor and protection via environmental barrier coating approach, J European Ceram Soc, 22 (2002) 2741-2747

${ }^{53}$ D Ding, W Zhou, F Luo, M Chen, D Zhu, Mechanical properties and oxidation resistance of $\mathrm{SiC}_{\mathrm{f}} / \mathrm{CVI}-$ SiC composites with PIP-SiC interphase, Ceram International 38 (2012) 3929-3934

${ }^{54}$ H Liu, H Cheng, J Wang, G Tang, Effects of single layer CVD SiC interphases on the mechanical properties of $\mathrm{SiC}_{\mathrm{f}} / \mathrm{SiC}$ composites fabricated by PIP process, Ceram International 36 (2010) 20332037

${ }^{55}$ Y Katoh, L L Snead, C H Henager, A Hasegawa, A Kohyama, B Riccardi, H Hegeman, Current status and critical issues for development of $\mathrm{SiC}$ composites for fusion applications, J Nucl Mater 367-370 (2007) 659-671

${ }^{56}$ T Nozawa, Y Katoh, L L Snead, The effect of neutron irradiation on the fiber/matrix interphase of silicon carbide composites, J Nucl Mater 384 (2009) 195-211

${ }^{57}$ T Nozawa, Y Katoh, L L Snead, The effect of neutron irradiation on shear properties of monolayered $\mathrm{PyC}$ and multilayered PyC/SiC interfaces in $\mathrm{SiC} / \mathrm{SiC}$ composites, J Nucl Mater 367-370 (2007) 685691

${ }^{58}$ K Dawi, M Balat-Pichelin, L Cahpentier, F Audubert, High temperature oxidation of SiC under helium with low-pressure oxygen. Part 3: - $\quad$ SiC-SiC/PyC/SiC, J European Ceram Soc 32 (2012) 485-494.

${ }^{59}$ L Charpentier, K Dawi, M Balat0Picheln, E Beche, F Audubert, Chemical degradation of SiC/SiC composites for the cladding of gas-cooled fas reactor in case of severe accident scenarios, Corrosion Sci 59 (2012) 127-135

${ }^{60} \mathrm{~S}$ Nogami, N Otake, A Hasegawa, Y Katoh, A Yoshikawa, M Satou, Y Oya, K Okuno, Oxidation behavior of $\mathrm{SiC} / \mathrm{SiC}$ composites for helium cooled solid breeder blanket, Fusion Energy Des 83 (2008) 1490-1494 
${ }^{61}$ G D Springer, C F Windisch, R H Jones, Stability of SiC/SiC composites in environments containing $\mathrm{O}_{2}$ and $\mathrm{H}_{2}$, J Nucl Mater 233-237 (1995) 1271-1274.

${ }^{62} \mathrm{D}$ F Wilson, Chemical compatibility issues associated with use of $\mathrm{SiC} / \mathrm{SiC}$ in advanced reactor concepts, ORNL/TM-2012/546 (November 2012) 